\title{
Human bartonellosis: seroepidemiological and clinical features with an emphasis on data from Brazil - A Review
}

\author{
C Lamas $/{ }^{1 /+}$, A Curi², MN Bóia ${ }^{1}$, ERS Lemos \\ Laboratório de Hantaviroses e Rickettsioses 'Laboratório de Doenças Parasitárias, Instituto Oswaldo Cruz-Fiocruz, Av. Brasil 4365, 21045-900 \\ Rio de Janeiro, RJ, Brasil '2Serviço de Oftalmologia, Instituto de Pesquisas Clínicas Evandro Chagas-Fiocruz, Rio de Janeiro, RJ, Brasil
}

Bartonellae are fastidious Gram-negative bacteria that are widespread in nature with several animal reservoirs (mainly cats, dogs, and rodents) and insect vectors (mainly fleas, sandflies, and human lice). Thirteen species or subspecies of Bartonella have been recognized as agents causing human disease, including B. bacilliformis, B. quintana, B. vinsonii berkhoffii, B. henselae, B. elizabethae, B. grahamii, B. washoensis, B. koehlerae, B. rochalimaea, and B. tamiae. The clinical spectrum of infection includes lymphadenopathy, fever of unknown origin, endocarditis, neurological and ophthalmological syndromes, Carrion's disease, and others. This review provides updated information on clinical manifestations and seroepidemiological studies with an emphasis on data available from Brazil.

Key words: Bartonella - infection - epidemiology - serology - Brazil

Members of the genus Bartonella are small, fastidious Gram-negative rod-shaped bacteria that parasitize mammalian erythrocytes and endothelial cells. Until 1993, Bartonella bacilliformis was the only recognized Bartonella species pathogenic to humans, responsible for Carrion's disease, which occurs in regions of Colombia, Ecuador and Peru. After molecular studies, four species belonging to the genus Rochalimaea were moved to the genus Bartonella, and at present, there are more than 23 recognized species (Brenner et al. 1993, Birtles et al. 1995) (Table I).

Several Bartonella species have been recovered from a wide range of wild and domesticated mammals throughout the world with a high diversity of geographic distributions, animal reservoirs, and arthropod vectors such as sandflies, the human body louse, the cat flea and, potentially, ticks (Podsiadly et al. 2007, Wikswo et al. 2007, Billeter et al. 2008). Contact with animals and vectors seem to be the most important mode of transmission, although recent studies have shown the ability of Bartonella to survive in stored blood for more than 35 days with the potential for transfusion-associated infection (Magalhães et al. 2007).

Thirteen species or subspecies of Bartonella have been recognized as agents causing human disease, including $B$. bacilliformis, $B$. quintana, $B$. vinsonii subsp. berkhoffii, B. henselae, B. elizabethae, B. grahamii, $B$. washoensis, $B$. koehlerae, and more recently, $B$. rochalimaea and B. tamiae, among others (Table I) (Regnery et al. 1992a, Birtles et al. 1995, Ellis et al. 1999, Kerkhoff et al. 1999, Chang et al. 2000, 2001, Jacomo et al. 2002, Holmberg et al. 2003, Kosoy et al. 2003, 2008, Bown et

Financial support: CAPES

+ Corresponding author: cristianelamas@gmail.com

Received 25 November 2007

Accepted 6 May 2008 al. 2004, Avidor et al. 2004, Castle et al. 2004, Jardine et al. 2005, Mediannikov et al. 2005, Chomel et al. 2006a, b, Diederen et al. 2007, Eremeeva et al. 2007, Li et al. 2007, Wikswo et al. 2007). Phylogenetic analysis using groEL sequences ( $g r o E L$ is a highly conserved heat-shock chaperonin protein) has distinguished four groups of Bartonellae: (1) two human pathogens $B$. henselae and $B$. quintana; (2) four rodent isolates, B. elizabethae, B. tribocorum, B. grahamii and B. taylorii; (3) a cluster including the $B$. vinsonii subspecies $(B$. vinsonii subsp. vinsonii, arupensis and berkhoffii); and (4) B. birtlesii and B. weissi. B. washoensis, B. alsatica, B. doshiae, $B$. bacilliformis, and $B$. clarridgeiae did not reliably cluster with any other Bartonella species (Zeaiter et al. 2002).

Bartonellae have pathogenic characteristics such as the ability to invade red blood cells and cause lysis of those cells, the ability to cause persistent bacteremia, and the ability to induce small vessel endothelial cell proliferation (Benson et al. 1986, Garcia et al. 1990, Battierman et al. 1995, Kordick \& Breitschwerdt 1995, Brouqui \& Raoult 1996, Resto-Ruiz et al. 2003). The pathologic response varies with immune status. In immunocompetent human individuals (IHI), the response is granulomatous and suppurative, whereas in immunodeficient patients, it is predominantly vasculoproliferative (Resto-Ruiz et al. 2003). This article reviews the current seroepidemiological studies of Bartonella infections as emerging infectious diseases and discusses presently identified clinical manifestations, emphasizing data available from Brazil.

\section{Seroepidemiologic studies}

The number of seroepidemiologic studies has grown significantly during the last ten years but more publications in human populations need be made available from the Southern Hemisphere (Table II). In Brazil, in 2001, a study of 457 Brazilian healthy adults from Piau, a small town in the state of Minas Gerais, showed 13.7 and $12.8 \%$ seroprevalence for $B$. henselae and B. quintana, respectively (cut off titer of 1:64). No correlation was 
TABLE I

Bartonella species associated and potentially associated with human disease, their distribution and vectors

\begin{tabular}{|c|c|c|c|}
\hline Species & Diseases & Distribution & Vector $^{b}$ \\
\hline B. bacilliformis & Carrion's disease & South America & $\begin{array}{l}\text { Sandflies } \\
\text { (Lutzomyia verrucarum) }\end{array}$ \\
\hline B. rochalimaea & $\begin{array}{l}\text { bacteremia, fever, cutaneous lesions } \\
\text { and splenomegaly }\end{array}$ & Peru & $\begin{array}{l}\text { unknown } \\
\text { (possibly L. verrucarum) }\end{array}$ \\
\hline B. quintana & $\begin{array}{l}\text { endocarditis, trench fever, CSD, } \\
\text { BA, peliosis hepatis }\end{array}$ & $\begin{array}{l}\text { South America, } \\
\text { Europe, USA, Africa }\end{array}$ & $\begin{array}{l}\text { human body louse } \\
\text { (Pediculus humanus } \\
\text { corporis), cat fleas, } \\
\text { gerbil fleas, Ixodes } \\
\text { pacificus ticks }\end{array}$ \\
\hline B. henselae & $\begin{array}{l}\text { CSD, ocular manifestations, encephalopathy, } \\
\text { aseptic meningitis, acute hemiplegia, } \\
\text { dementia, acute psychiatric symptoms, FUO, } \\
\text { hepatosplenic abscesses, asymptomatic } \\
\text { bacteremia, osteomyelitis, BA, peliosis hepatis, } \\
\text { erythema nodosum, other skin lesions }\end{array}$ & $\begin{array}{l}\text { South America, Europe, } \\
\text { USA, Africa, Asia }\end{array}$ & $\begin{array}{l}\text { cat flea (Ctenocephalides } \\
\text { felis), Ixodes ricinus ticks, } \\
\text { I. pacificus ticks, Riphi- } \\
\text { cephalus sanguineus ticks } \\
\text { (dogs) }\end{array}$ \\
\hline B. elizabethae & endocarditis & Europe, USA, Asia & $\begin{array}{l}\text { rat fleas (genera Rattus } \\
\text { and } M u s \text { ), wild rodent } \\
\text { fleas }\end{array}$ \\
\hline B. clarridgeiae & CSD, sepsis, endocarditis & Europe, USA, Asia & $\begin{array}{l}\text { cat flea }(C \text {. felis), rodent } \\
\text { fleas, dog ectoparasites(?), } \\
\text { gray foxes ectoparasites(?) }\end{array}$ \\
\hline B. clarridgeiae-like & fever and splenomegaly & Peru & unknown \\
\hline B. koehlerae & endocarditis, CSD & USA & Cat and rodent fleas \\
\hline $\begin{array}{l}\text { B. vinsonii } \\
\text { subsp. berkhoffii }\end{array}$ & $\begin{array}{l}\text { endocarditis, } \\
\text { arthralgia/myalgia/headache/fatigue }\end{array}$ & Europe, USA & $\begin{array}{l}\text { I. pacificus ticks, coyote } \\
\text { ticks(?) } \\
\text { gray foxes ectoparasites(?) }\end{array}$ \\
\hline B. washoensis & fever and myocarditis & USA & $\begin{array}{l}\text { I. pacificus ticks, ground } \\
\text { squirrels }\end{array}$ \\
\hline B. tamiae & fever & Thailand & unknown \\
\hline B. grahamii & neuroretinitis & Europe, Canada, Asia & $\begin{array}{l}\text { vole fleas, other wild } \\
\text { rodents fleas(?) }\end{array}$ \\
\hline B. doshiae & CSD & Europe & $\begin{array}{l}\text { rat fleas (genera Rattus } \\
\text { and } M u s \text { ) }\end{array}$ \\
\hline B. taylorii & unknown & Europe & gerbil fleas, vole fleas \\
\hline B. alsatica ${ }^{a}$ & unknown & Europe & vector unknown \\
\hline B. bovis & unknown & $\begin{array}{l}\text { Europe, Africa, } \\
\text { North America }\end{array}$ & ticks \\
\hline
\end{tabular}

$a$ : B. alsatica has been isolated from the blood of wild rabbits; $b$ : so far ticks have not been shown experimentally to transmit Bartonella spp to human beings; voles and gerbils are wild rodents; BA: bacillary angiomatosis; CSD: cat scratch disease; FUO: fever of unknown etiology.

found with job exposure, living in a rural area or sex, but individuals over 40 had a tendency toward higher seroprevalence (Costa et al. 2005). Another study was conducted in 2005 in 125 consecutive outpatient clinically asymptomatic HIV-positive patients in Jacarepaguá, a semi-rural area of Rio de Janeiro city, in which Bartonella sp. seroprevalence was 41.6\% (cut-off titer of 1:20). These individuals were young (mean age $37 \pm 10$ years) and none were intravenous drug users. The only iden- tified risk factor for Bartonella infection was breeding cats, which had an odds ratio of 3.6. No differences were found in CD4 cell count, sex, age, exposure to dogs, rodents, ticks, fleas or lice (Lamas et al. 2006).

From the data presented in Table II and those discussed above, it is clear that Bartonella largely circulates among human populations (Jackson et al. 1996, Brouqui et al. 1996, 1999, 2005, Comer et al. 1996, 2001, Rotily et al. 1996, Noah et al. 1997, Blanco et al. 1998, 1999, 
TABLE II

Bartonella human seroprevalence in selected populations in the last decade (1996-2007) by country and chronological order of publication

\begin{tabular}{|c|c|c|c|c|}
\hline Country & $\begin{array}{l}\text { Number } \\
\text { of individuals }\end{array}$ & Population/Bartonella species & $\begin{array}{l}\text { Positive } \\
(\%)\end{array}$ & Reference \\
\hline \multirow[t]{2}{*}{ USA } & 192 & $\begin{array}{l}\text { clinic patients (homeless, alcoholic, } \\
\text { HIV-negative) }\end{array}$ & 20 & \multirow[t]{2}{*}{ Jackson et al. (1996) } \\
\hline & 199 & $\begin{array}{l}\text { age- and sex-matched blood } \\
\text { donors/ B. quintana }\end{array}$ & 2 & \\
\hline USA & 630 & $\begin{array}{l}\text { IVDU from Baltimore/Bartonella spp., } \\
\text { B. elizabethae, B. henselae, B. quintana }\end{array}$ & \multirow[t]{2}{*}{$37.5,22.9,1.4,1.6$} & Comer et al. (1996) \\
\hline USA & 351 & $\begin{array}{l}\text { veterinarians, vet technicians, other } \\
\text { individuals attending a conference/ } \\
B . \text { henselae and B. quintana }\end{array}$ & & Noah et al. (1997) \\
\hline USA & 146 & children with $\mathrm{FUO} / B$. henselae & 4.8 & Jacobs et al. (1998) \\
\hline USA & 204 & $\begin{array}{l}\text { IVDU from New York/ } \\
\text { B. elizabethae, B. henselae, } \\
\text { B. quintana }\end{array}$ & $46,10,2$ & Comer et al. (2001) \\
\hline USA & 200 & $\begin{array}{l}\text { clinic patients/ B. elizabethae, } \\
\text { B. quintana, B. henselae }\end{array}$ & $12.5,9.5,3.5$ & Smith et al. (2002) \\
\hline USA & 382 & $\begin{array}{l}\text { HIV-positive patients } \\
\text { with fever/ Bartonella spp. }\end{array}$ & 17 & Koehler et al. (2003) \\
\hline France & 71 & homeless patients/ B. quintana & 30 & Brouqui et al. (1996) \\
\hline France & 57 & $\begin{array}{l}\text { adult homeless with cutaneous } \\
\text { infestation/ B. quintana }\end{array}$ & 54 & Guibal et al. (2001) \\
\hline & 53 & blood donors/ $B$. quintana & 2 & \\
\hline $\begin{array}{l}\text { France, Eastern } \\
\text { Europe and } \\
\text { Northern Africa }\end{array}$ & 930 & homeless mainly from France/ B. quintana & 7.5 & Brouqui et al. (2005) \\
\hline Germany & 270 & healthy adults/ $B$. henselae & 30 & Sander et al. (1998) \\
\hline Greece & 500 & healthy adults/ $B$. henselae, $B$. quintana & $19.8,15$ & Tea et al. (2003) \\
\hline Greece & 63 & healthy children/ Bartonella spp. & 15.9 & Antoniou et al. (2002) \\
\hline Italy & 508 & healthy children/ $B$. henselae & 61.6 & Massei et al. (2004) \\
\hline Spain & $\begin{array}{l}83 \\
85\end{array}$ & $\begin{array}{l}\text { cat owners } \\
\text { blood donors/ } B \text {. henselae }\end{array}$ & $\begin{array}{c}28.9 \\
5.9\end{array}$ & Blanco Ramos Jr et al. (1998) \\
\hline Spain & $\begin{array}{r}147 \\
94\end{array}$ & $\begin{array}{l}\text { HIV-positive IVDU } \\
\text { HIV negative IVDU/Bartonella spp. }\end{array}$ & $\begin{array}{l}14 \\
15\end{array}$ & Ramos AJ et al. (2002) \\
\hline Spain & 146 & healthy individuals/ Bartonella spp. & 24.7 & Garcia-Garcia et al. (2005) \\
\hline Sweden & 498 & $\begin{array}{l}\text { blood donors/ B. elizabethae, B. grahamii, } \\
\text { B. henselae, B. quintana }\end{array}$ & $\begin{array}{l}14.1,2.6 \\
1.2,0.2\end{array}$ & McGill et al. (2005) \\
\hline United Kingdon & 200 & blood donors/ B. henselae, $B$. quintana & 1.5 & Harrison and Dosh (1999) \\
\hline Jordan & 482 & children/ B. henselae, B.quintana & $11,4.1$ & Al-Majali and Al-Qudah (2004) \\
\hline Japan & 233 & veterinary professionals/ $B$. henselae & 15 & Kumasaka et al. (2001) \\
\hline Japan & $\begin{array}{l}159 \\
129\end{array}$ & $\begin{array}{l}\text { patients with cardiovascular } \\
\text { disease, veterinary students/ B. henselae }\end{array}$ & $\begin{array}{c}3.1 \\
10.1\end{array}$ & Kikuchi et al. (2002) \\
\hline Japan & $\begin{array}{l}151 \\
200\end{array}$ & homeless, blood donors/ B. quintana & $\begin{array}{l}57 \\
51\end{array}$ & Seki et al. (2006) \\
\hline Thailand & 163 & healthy individuals/ $B$. henselae & 5.5 & Maruyama et al. (2000) \\
\hline New Zealand & 140 & healthy blood donors/ $B$. henselae & 5 & Zarkovic et al. (2007) \\
\hline Brazil & 437 & adult healthy individuals/ $B$. henselae, $B$. quintana & $\begin{array}{l}13.7 \\
12.8\end{array}$ & Costa et al. (2005) \\
\hline Brazil & 125 & HIV-seropositive asymptomatic adults/ $B$. henselae & 40.8 & Lamas et al. (2006) \\
\hline Chile & $\begin{array}{l}181 \\
107\end{array}$ & $\begin{array}{l}\text { children and adolescents } \\
\text { adult cat carers/ } B \text {. henselae }\end{array}$ & $\begin{array}{l}13.3 \\
10.3\end{array}$ & Ferrés et al. (2006) \\
\hline
\end{tabular}




\begin{tabular}{|c|c|c|c|c|}
\hline Country & $\begin{array}{l}\text { Number } \\
\text { of individuals }\end{array}$ & Population/Bartonella species & $\begin{array}{l}\text { Positive } \\
\qquad(\%)\end{array}$ & Reference \\
\hline Ecuador & 213 & $\begin{array}{l}\text { serosurvey of close contacts of cases of } \\
\text { Carrion's disease/ B. bacilliformis }\end{array}$ & 18.5 & Amano et al. (1997) \\
\hline Peru & 544 & $\begin{array}{l}\text { children and adults in an area with an outbreak } \\
\text { of Carrion disease/ B. bacilliformis }\end{array}$ & 77.5 & Kosek et al. (2000) \\
\hline Peru & 690 & $\begin{array}{l}\text { chidren and adults in endemic } \\
\text { area/ B. bacilliformis }\end{array}$ & 45 & Chamberlin et al. (2002) \\
\hline
\end{tabular}

FUO: fever of unknown etiology; IVDU: intravenous drug user.

Jacobs \& Schutze 1998, Sander et al. 1998, Harrison \& Doshi 1999, Maruyama et al. 2000, Guibal et al. 2001, Kumasaka et al. 2001, Antoniou et al. 2002, Kikuchi et al. 2002, Ramos et al. 2002, Smith et al. 2002, Tea et al. 2003, Koehler et al. 2003, Al-Majali \& Al-Qudah 2004, Massei et al. 2004, Garcia-Garcia et al. 2005, McGill et al. 2005, Ferres et al. 2006, Seki et al. 2006, Ehrenborg et al. 2007, Zarkovic et al. 2007). B. bacilliformis serology performed in endemic areas is notably high (Amano et al. 1997, Kosek et al. 2000, Chamberlin et al. 2002). $B$. henselae seropositivity has a close association with cat ownership and/or cat care (for example, veterinary professionals) (Rath et al. 1997, Chang et al. 2002, 2006, Schattner et al. 2003, Podsiadly et al. 2007). B. quintana seropositivity is linked to homelessness, alcoholism, infestation, and animal exposure (Spach et al. 1995b, Stein \& Raoult 1995, Brouqui et al. 1996, Abbott et al. 1997, Guibal et al. 2001, Boulouis et al. 2005). B. henselae and $B$. vinsonii subsp. berkhoffii have been isolated in blood of IHI with frequent animal and arthropod contact (Breitschwerdt et al. 2007a, b).

In relation to Bartonella spp. infections in animals, pets, especially cats, represent a large reservoir for human infection (Skerget et al. 2003, Chomel et al. 2006a, b). Cats are the main reservoir for B. henselae, B. clarridgeiae and B. koehlerae (Regnery et al. 1990, Groves \& Harrington 1994, Lawson \& Collins 1996, Gurfield et al. 1997, Heller et al. 1997, Chomel et al. 1999, Zanutto et al. 2001). Although they are well-adapted hosts to Bartonellae, several clinical and experimental studies have shown cats may become ill with the infection (Regnery et al. 1996, Kordick et al. 1999, O’Reilly et al. 1999).

Dogs can be infected with $B$. vinsonii subsp. berkhoffii, B. henselae (Tsukahara et al. 1998), B. clarridgeia, B. washoensis (Chomel et al. 2003), B. elizabethae, $B$. quintana, and B. bovis. The role of dogs as an important reservoir for Bartonella spp. (Honadel et al. 2001, Henn et al. 2005, 2006) is less clear than that for cats because domestic dogs are more likely to be accidental hosts, at least in tropical regions. However, dogs may be sentinels for human infections because they may become ill (Chomel et al. 2006a, b, Henn et al. 2007). Transmission of B. henselae by cat fleas is well-understood, though new potential vectors (ticks and biting flies) have also been identified (Chomel et al. 2006a, b, Podsiadly et al. 2007, Wikswo et al. 2007, Billeter et al. 2008).

Transmission of $B$. quintana from a cat to a human individual has been documented by molecular biological methods (MBM) and the putative mode of transmission was a cat bite (Breitschwerdt et al. 2007b). Although human transmission by ticks has not been proven, several recent studies have identified Bartonella DNA in ticks attached to humans (Adelson et al. 2004).

Seroprevalence in cats varies from 14 to $50 \%$ across studies, and it has been reported that cats may have persistent and asymptomatic bacteremia (Koehler et al. 1994, Baneth et al. 1996, Bergmans et al. 1997, Chomel et al. 1999, 2002, 2006a, b, Hjelm et al. 2002, Fabbi et al. 2004). A study by Slhessarenko et al. (1996) on the seroprevalence of cats in the city of São Paulo, Brazil, revealed $46 \%$ sero-reactivity to Bartonella spp.

$B$. koehlerae has been isolated from cats and cat fleas, and has been linked to human disease (Rolain et al. 2003, Avidor et al. 2004, Chomel 2006a). B. koehlerae and $B$. clarridgeiae have also been detected by MBM in cat fleas (Rolain et al. 2003). B. quintana was thought, until recently, to have only humans as a reservoir species, but recent publications have shown that it is also present in dogs (La et al. 2005), cats, cat fleas (Rolain et al. 2003), and even monkeys (O'Rourke et al. 2005).

In dogs, $B$. quintana and $B$. clarridgeae have been shown to cause endocarditis (Kelly et al. 2006). B. vinsonii subsp. berkhoffii has been shown to cause endomyocarditis and arrhythmias (Breitschwerdt et al. 1995, 1999), and its seroprevalence in dogs has been reported as high (Solano-Gallego et al. 2004, Henn et al. 2006). Coyotes seem to be its wild reservoir (Chang et al. 2000). A recent study in Brazil (Diniz et al. 2007) analyzed the serological and molecular prevalence of Bartonella spp. in sick dogs: 4/197 (2\%) were seroreactive to $B$. henselae and 3/197 (1.5\%) to B. vinsonii subsp. berkhoffii. DNA amplification showed co-infection with both species.

B. elizabethae has been isolated from the blood of Rattus rattus and from the rat flea Xenopsylla cheopis. Despite the association of $B$. elizabethae with rodents, Hjelm et al. (2002) found a seroprevalence of $25 \%$ in 292 cats studied in Sweden. Other Bartonella species that are less important in causing human disease have been identified in ground squirrels (B. washoensis), and wild felids have been shown to be naturally infected with $B$. henselae variants (Chomel 2006a, b). A recent study in Brazil (Filoni et al. 2006) showed a prevalence of $95 \%$ $(20 / 21)$ of $B$. henselae in wild felids from different biomes. B. bovis (previously weisii) has been identified in cattle from Europe, North America and Asia, but no role in human disease has been established to date (Bermond et al. 2002, Raoult et al. 2005, Maillard et al. 2006). 


\section{Clinical manifestations}

The clinical spectrum of Bartonella infections has continually expanded. Besides classical diseases such as Carrion's (Ricketts 1949) and cat-scratch disease (CSD) (Wear et al. 1983), others, such as relapsing bacteremia, endocarditis, and trench fever occur today mainly in socio-demographic niches such as poor urban areas and refugee camps (Stein \& Raoult 1995).

Bacillary angiomatosis (BA) and hepatic peliosis, classically associated with Acquired Immunodeficiency Syndrome (AIDS) (Regnery et al. 1995) is seen less frequently today, possibly due to earlier recognition of HIV serostatus and a reduced number of individuals with CD4 lymphocyte cell counts below 50 cells $/ \mathrm{mm}^{3}$.

Bartonella infections that deserve detailed discussion based on their increasing number of reports include blood culture negative infective endocarditis and fever of unknown origin. In addition, for several decades atypical manifestations of CSD such as meningoencephalitis, retinitis, dissemination with hepatosplenic abscesses and osteomyelitis have been reported, and it is likely that many such manifestations still go unrecognized (Stevens 1952, Adams \& Hindman 1954, Selby \& Walker 1979, Miller \& Bell 1980, Johnson et al. 1985, Wear et al. 1985, Katner et al. 1986, Greenbaum et al. 1986, Lewis \& Tucker 1986, Margileth et al. 1987, Chrousous et al. 1990, Apalsch et al. 1993, Golden 1993, Tappero et al. 1993, Bernini et al. 1994, Waldwogel et al. 1994, Hadley et al. 1995, Whitman \& Krafte-Jacobs 1995, Wong et al. 1995, Riviello \& Ruoff 1998, Walter \& Eppes 1998, Arisoy et al. 1999, Hulzebos et al. 1999, Maggiore et al. 1999, Robson et al. 1999, Ventura et al. 1999, Azevedo et al. 2000, Krause et al. 2000, Hmaimess et al. 2004, Baylor et al. 2007, Stockmeyer et al. 2007). The onset of signs and symptoms of bartonellosis generally occur about one to two weeks after exposure, but this delay can range from 1-4 weeks, depending on the syndrome presented, and may last several months (Carithers 1985).

Lymphadenopathy - Lymphadenopathy, usually of lymph nodes draining the site of inoculation (axillary, epitrochlear, neck, and jaw nodes being most frequently affected) of the bacteria, is the most constant feature of CSD. More than $85 \%$ of cases have single lymph node chain involvement, and 2-4 nodes may be enlarged. Nodes may be tender and have inflamammatory signs (erythema, tenderness, warmth) and suppurate in 13 to $48 \%$ of cases (Daniels \& McMurray 1954, Carithers 1985). They may reach several centimeters in diameter and may persist for about two weeks to several months. Lymphadenopathy is associated with an inoculation papule in most cases, but the papule may go unrecognized when the patient is brought to the physician's attention three or more weeks after contact with a cat. It is unassociated with fever in about $40 \%$ of cases (Carithers 1985). CSD is an important cause of lymphadenopathy of the head and neck (Ridder et al. 2002).

Cat scratch disease affects children and young adults more often, but many cases may go undiagnosed in older adults. Exposure to cats, often young, is the rule. Seasonality is different in the Southern (December and
January, summer school vacation and exposure to pets; Huarcaya et al. 2002) and Northern hemispheres (late fall and early winter, September to February; Spaulding \& Hennessy 1960, Carithers 1985, Zangwill et al. 1993, Hamilton et al. 1995).

A few reports of generalized lymphadenopathy and of mediastinal masses due to Bartonella infection have been published (Katner et al. 1986, Tolan et al. 1990, Apalsch et al. 1993). However, the most common manifestation associated with lymphadenopathy is conjunctivitis, characterizing Parinaud oculoglandular syndrome. In this case, enlarged nodes are pre-auricular and there is a characteristic granulomatous lesion on the ipsilateral conjunctiva; its frequency in large series of CSD is around 5\% (Carithers 1985, Margileth 1992). Most often, the conjunctivitis is painless and does not present discharge. More information about ocular manifestations will be presented in the next section. Cases of CSD have been confirmed in Brazil, as observed by testing of biological samples in the reference laboratory in Fiocruz (unpublished observation). A case of CSD caused by $B$. quintana that was associated with cat contact deserves mention since it is one of the first observations of the possibility of cat-related infection with B. quintana (Azevedo et al. 2000).

Ocular manifestations - The ocular manifestation of CSD was initially reported as a chronic ulcerative conjunctivitis associated with lymphadenopathy, named Parinaud oculoglandular syndrome (POGS), as noted above. Several reports have since confirmed the association between POGS and cat exposure. It was only in 1970, when Sweeny and Drance described a possible association between neuroretinitis and cat-scratch disease, that intra-ocular changes secondary to CSD began to be considered. These findings were confirmed by Gass (1977), and in the last two decades, several studies have been published regarding intra-ocular manifestation of CSD. Intra-ocular changes secondary to $B$. henselae infection include neuroretinitis, sub-retinal lesions, retinitis, intermediate uveitis, inflammatory masses, and angiomatous lesions. Other findings are occlusive events, retinal serous detachment and optic neuritis. Despite the variety of ocular manifestations, neuroretinitis, small foci of retinitis, and angiomatous lesions are the most common ocular findings in CSD. Neuroretinitis is the second most common ocular finding. Neuroretinitis secondary to CSD presents with unilateral or bilateral involvement and is characterized by blurred vision from 20/25 to light perception, optic disk edema, serous detachment, and macular star. Patients may present with central scotoma and papillary defects. Studies have suggested that neuroretinitis secondary to CSD is a benign disease and visual acuity returns to normal within approximately four weeks without treatment. Although many patients show good recovery without treatment, some authors have suggested oral treatment in cases of severe ocular symptoms and systemic complications. Solley et al. (1999) reported 24 patients with the diagnosis of CSD and ocular disease in the posterior segment of the eye. In this study, the most common finding was 
small whitish lesions in the retina or choroid measuring from 50 to $3000 \mu \mathrm{m}$. Ormerod et al. (1998) reported two cases of CSD presenting with several small whitish lesions, choroidal infiltrates, and vascular occlusions.

Several small case series have been published regarding Bartonella infection and its ocular manifestations. Neuroretinitis has been considered in most of these series as the major ocular manifestation of CSD (Reed et al. 1998, Suhler et al. 2000, Kodama et al. 2003). Other studies showed granuloma of the optic disk associated with abnormal vascular network as the hallmark of intraocular CSD. Wade et al. (2000) published a case series of seven patients presenting with disc edema and peripapillary serous retinal detachment. Isolated cases of CSD and unusual ocular changes have been described. Soheilian et al. (1996) described a case of intermediate uveitis in a young man with CSD. The patient presented with retinal vasculitis and vitritis. Pollock \& Kristinsson (1998) reported a case of helioid unifocal choroiditis secondary to CSD. This syndrome was first described by Hong et al. (1997) in patients presenting with solitary yellowish lesions without any infectious or inflammatory associated conditions. Other rare associations include inflammatory masses and lesions mimicking the VogtKoyanagi-Harada syndrome.

In Brazil, few publications are available, but recently, more attention is being given to this zoonosis, mainly in HIV-positive patients in whom ocular manifestations are different from IHI. Single case reports have been described in the Brazilian ophthalmological literature regarding intraocular changes secondary to CSD. Amaro (1996) reported a case of CSD and retinal infiltrates. The same author (Amaro 1998) described a case of neuroretinits and CSD. Curi et al. (2006) showed the presence of angiomatous lesions in retinal vessels in HIV-positive patients. The lesions showed good response to oral therapy. Another publication by the same author (Curi et al. 2003) described a case of helioid unifocal choroiditis in an HIV-positive patient with CSD. Additionally, a Brazilian case of Parinaud's, involving a 9-year-old child, was published in the 1990s (Yamashita et al. 1996). More recently, a case of granulomatous conjunctivitis in a 23-year-old female, without lymph node involvement, was reported (Oliveira et al. 2004).

Neurological complications - Several neurological manifestations of Bartonella infections have been described (Lyon 1971, Carithers \& Margileth 1991). They are, in order of frequency: seizures with encephalopathy, status epilepticus and coma, neuroretinitis, aseptic meningitis, transverse myelitis, radiculitis, cerebral arteritis, acute hemiplegia, and dementia (Stevens 1952, Selby \& Walker 1979, Miller \& Bell 1980, Carithers 1985, Lewis \& Tucker 1986, Baker et al. 1995, Hadley et al. 1995, Hamilton et al. 1995, Noah et al. 1995, Schwartzman et al. 1995, Wong et al. 1995, Riviello \& Ruoff 1998, Walter \& Eppes 1998, Hmaimess et al. 2004, Rocha et al. 2004, Stockmeyer et al. 2007, Baylor et al. 2007). Overall neurological complications account for 1-2\% of cases of CSD (Carithers 1985, Carithers \& Margileth 1991, Noah et al. 1995).
Bartonella encephalopathy was first reported in 1952 (Stevens 1952), and others described it years later. Seizures are a common associated manifestation occurring in nearly half of the cases in some series, and some patients develop status epilepticus lasting several hours or even days. Combative behaviour follows seizures or status epilepticus, but full recovery is generally achieved (Carithers 1985, Carithers \& Margileth 1991). Encephalopathy occurs more often in older children and adults (Carithers 1985, Carithers \& Margileth 1991, Hadley et al. 1995, Rocha et al. 2004) and usually follows lymphadenopathy by 2-6 weeks.

Clusters of cases have also been described by Noah et al. (1995). After finding five cases of encephalopathy in children in a limited geographic area, the authors studied cats in the area where affected children were diagnosed. Cats had a seropositivity of $62 \%$ and bacteremia was detected in $22 \%$. Cases with unusual associations, such as pleural effusions, have also been described (Whitman \& Krafte-Jacobs 1995).

A case of acute hemiplegia in an 11-year-old Brazilian patient has been published recently (Rocha et al. 2004). This patient had a slight pleocytosis on cerebrospinal fluid (CSF) analysis and a magnetic resonance scan with a non-enhancing subcortical fronto-parietal lesion. He was discharged from the hospital still exhibiting neurological motor signs, and no details on permanent sequels were provided by the authors. It is hypothesized that the mechanism of neurological damage was vasculitis.

Aseptic meningitis is rarely described in Bartonella infections; only four cases (one in a HIV-seropositive patient) have been reported to date, one of which was in Brazil (Wong et al. 1995, Lucey et al. 1992, Pinto Jr et al. 2008). The Brazilian case was of a 40 - year-old male who presented with visual blurring in addition to lymphadenopathy and persistent headache. Optic neuropathy with optic disk swelling and the presence of a partial macular star was noted on funduscopy. These findings characterize neuroretinitis. CSF analysis showed slight pleocytosis and tomographic brain scans were normal. Wong et al. (1995) described an incidence of 5/19 IHI and 1/4 HIVpositive individuals with Bartonella (CSD, lymphadenopathy, fever of unknown etiology, etc) infection presenting with stellate retinitis in a series collected between 1991 and 1993, showing its relatively high incidence.

Cognitive decline has been associated with cat ownership in HIV-positive patients (Schwartzman et al. 1995). A report of two patients with psychiatric symptoms (depression and psychosis) associated with BA and HIV showed resolution of manifestations with antibiotic treatment (Baker et al. 1995). Possibly due to earlier diagnosis of HIV seropositivity, neurological manifestations such as dementia, associated or not with Bartonel$l a$, and other psychiatric features, have been uncommon in recent years.

Fever of unknown etiology (FUO) - Prolonged fever (of more than 4 weeks duration), not associated with regional or systemic lymphadenopathy, may be a manifestation of Bartonella infection. It usually does not exceed $39^{\circ} \mathrm{C}$ (Carithers 1985). Jacobs and Schutze (1998) report- 
ed 7/146 children with FUO who had Bartonella infection: all had temperatures above $38^{\circ} \mathrm{C}$ for more than four weeks, and these fevers were associated with malaise, listlessness, headache, and anorexia in some of these children. Six of the seven had had contact with cats. In two, hepatosplenic abscesses were found. A recent series (Murakami et al. 2002) reported 2.8\% FUO in 130 patients, nearly a third of which lacked lymphadenopathy. Recurrent infection may occur (Margileth et al. 1987). In HIV-positive patients, Bartonella may also be the cause of FUO (Koehler et al. 2003).

Hepatosplenic abscesses - Hepatosplenomegaly, often associated with fever, has been reported in several papers (Greenbaum et al. 1986, Golden 1993, Waldwogel et al. 1994, Arisoy et al. 1999, Ventura et al. 1999, Rolain et al. 2003). Despite feeling feverish, most patients are not unwell and most give a history of cat exposure. Ultrasound scans are mandatory in the evaluation of FUO, and may reveal nodules, $2-3 \mathrm{~cm}$ in diameter, which resolve with calcification (Golden 1993). There may be associated intraabdominal lymphadenopathy. A case of right axillary lymphadenopathy and systemic CSD in a 12-year-old boy with liver transplantation has been reported, showing that immunosuppression may play a role in dissemination (Apalsch et al. 1993). However, bacillary angiomatosis and bacillary splenitis have been reported in adult IHI (Tappero et al. 1993). Splenomegaly, lasting several weeks, was reported in 4/18 cases of severe CSD, and abscesses were identified in one of these (Margileth 1992). Granulomatous hepatitis caused by Bartonella has probably been under diagnosed (Golden 1993).

Cardiovascular complications - Myocarditis, pericarditis, and endocarditis have been described in animals infected with Bartonella (Breitschwerdt et al. 1995, 1999). In human beings, however, endocarditis is the main associated feature. Clinical features of Bartonella infective endocarditis (IE) are persistent fever, with left sided valve involvement being the most common (the aortic valve in $66 \%$, the mitral in $18 \%$ and both in $13 \%$ ). Embolic phenomena are common, especially petechiae, splinters and purpura, as the course tends to be subacute. For the same reason, splenomegaly and digital clubbing may be seen, as may glomerulonephritis, clinically manifested as haematuria. Vegetations are detected in most (over $90 \%$ ) of the cases by transthoracic echocardiograms. Patients tend to be younger than those in usual series of endocarditis (Fournier et al. 2001, Raoult et al. 2003) with a mean age of 45 versus 55 years.

Bartonella endocarditis has been recognized since the first reports from the 1990s (Hadfield et al. 1993, Daly et al. 1993, Spach et al. 1993, 1995a, Drancourt et al. 1995, Holmes et al. 1995, Mainardi et al. 1996, Breathnach et al. 1997, Bruneel et al. 1998) and its importance in blood-culture negative infective endocarditis (BCNE) has been reinforced in recent series (Hoen et al. 1995, Raoult et al. 1996, Fournier et al. 2001, Lamas \& Eykyn 2003, Houpikian \& Raoult 2005). So far, B. quintana has been the most frequently identified species, with $B$. henselae, B. vinsonii subsp. berkhoffi (Roux et al. 2000), B. elizabethae (Daly et al. 1993), and B. koehlerae (Avidor et al. 2004) being infrequently reported (one case each).
A recent and large series of $\mathrm{BCNE}$ cases revealed that $99 / 348(28 \%)$ of cases were caused by Bartonella spp. Of these, 53 of 99 (75\%) were B. quintana, 17 (24\%) were $B$. henselae, and 1 was $B$. vinsonii subsp. berkhoffii (Houpikian \& Raoult 2005). Although most studies on BCNE are European or American, two studies (Benslimani et al. 2005, Znazen et al. 2005), showed that Bartonella is a worldwide problem and may actually be more prevalent in developing countries. In a study from Algeria (Benslimani et al. 2005), of 62 cases of BCNE, $B$. quintana was identified by serum immunofluorescence or polymerase chain reaction in 14 . This represented $50 \%$ of the cases that had a defined etiology, since in 34 of 62 cases of BCNE, no microorganism was detected. This population had a high prevalence of rheumatic heart disease as a predisposing condition to IE. A study from Tunisia (Znazen et al. 2005) proposed to analyze seroreactivity to Bartonella in 40 samples that had tested positive for Chlamydia sp. High levels of antibody (titer above 1:800 by indirect immunofluorescent assay - IFA) were found in samples from 13 individuals, 11 of whom had definite endocarditis by the Duke criteria. Molecular biological studies showed that ten were B. quintana and one was $B$. henselae. Most patients were of rural origin and had poor living conditions, and nearly $2 / 3$ had predisposing valvulopathy. Despite the well-described relationship between acquiring $B$. henselae disease and cat exposure, and the relationship between poor personal hygiene and homelessness and $B$. quintana disease, the mode of transmission of $B$. quintana is not completely clarified. With the more widespread description of $B$. quintana in nature, more associations will likely be reported in the near future.

The first Brazilian case of Bartonella endocarditis, alive and well, has been recently published (Lamas et al. 2007). It shows features of Bartonella IE that are similar to what is already described in the literature. The patient had predisposing valvular disease (the 46 year-old patient had rheumatic heart disease), absence of fever, exposure to a young cat at home in the months preceding progressive heart failure, the need for valvular surgery (as is often the case with aortic valve involvement), and a good response to an antibiotic regime containing penicillin, gentamycin and doxycycline (Raoult et al. 1996, 2003, Fournier et al. 2001). The diagnosis was made retrospectively based on very high IgG titers (1:4096) to $B$. henselae in serum collected prior to antibiotic therapy, and lower levels (1:512) 14 months after completion of specific treatment. Two possible cases of IE have also been reported by Siciliano et al. (2006) in Brazil. One patient had native aortic valve IE and the other a prosthetic aortic valve IE, and both had domestic cats. Diagnosis was based on only one serological sample analysis. No details on associated conditions were mentioned and the patients died rapidly ( 7 and 10 days post admission). The diagnosis was made post mortem.

Skin manifestations - Two main syndromes in Bartonella disease involve the skin: bacillary angiomatosis in immunocompromised (but also in IHI) adults, and Carrion's disease in its chronic form (verruga peruana). 
Skin lesions in HIV-positive patients are proliferative vascular lesions. They may resemble Kaposi's sarcoma, angiomatous nodules, red papules, pedunculated lesions, or deep subcutaneous masses (Regnery et al. 1995, Mohle-Boetani et al. 1996). These patients usually present low CD4 counts (average 30 cells $/ \mathrm{mm}^{3}$ ), fever and weight loss, representing advanced disease. Tappero et al. (1993) published a case control study on bacillary angiomatosis and found, among the 48 case patients, only five HIV negative IHI. Variables associated with disease acquisition, by multivariate analysis, both involved traumatic contact with cats (bite or scratch). No association was found to exposure to insect bites or to terrains.

In Brazil, a case report on a 49 year-old female patient has been published (Velho et al. 2006). She had associated AIDS and scabies, and on physical examination, numerous papules and subcutaneous nodules were present, as well as hepatosplenomegaly. A more recent publication by the same authors (Velho et al. 2007) describes a case of cryptogenic hepatitis, anaemia, and panserositis in an HIV patient with bacillary angiomatosis. $B$. henselae was isolated by MBM and the patient responded to clarithromycin. A case series of 13 patients, collected between 1990 and 1997 (before highly active antiretroviral therapy availability in Brazil) was published (Gazineo et al. 2001). All patients were male, the mean age was 39 years, and the mean CD4 count was 90 . Calculated incidence rate of $\mathrm{BA}$ was low but comparable to the world literature. Angioproliferative lesions of the liver (peliosis hepatitis) and spleen may be associated with the cutaneous lesions.

A recent report on Peruvian warts (Maguiña et al. 2001) included 77 patients. Their lesions were classified into three types: miliary, nodular, and mular. The miliary form consists of several 1-4 mm papules, which are round, erythematous, and often pruritic. They accounted for most cases (69\%) and involved the lower limbs. Nodular or subdermic lesions are usually present as few cutaneous nodules with no inflammatory reaction. Mular lesions are erythematous, greater than $5 \mathrm{~mm}$ in diameter and bleed easily. Secondary infection occurred in $12 \%$ of cases and bleeding complicated $66 \%$. The most frequently associated features, besides the skin manifestations, were fever (44\%), malaise (53\%), arthralgia (47\%), pallor (47\%), lymphadenopathy (29\%) and headaches $(25 \%)$.

\section{Carrion's disease}

Carrion's disease has its name because of Daniel Carrion, a Peruvian medical student who inoculated himself in 1885 with material extracted from a wart. Within weeks, he developed the acute phase of the disease, with fever, haemolysis, and severe immunossupression (Oroya fever), which eventually killed him (Ricketts 1949). He established, therefore, that the same agent (B. bacilliformis) was the cause of the acute and chronic forms of the bartonellosis. B. bacilliformis was described in 1905 within erythocytes. Differently from other species in the genus, it is transmitted by a sandfly, Lutzomyia verrucarum. Bartonellosis is still endemic in some areas in Peru, Ecuador and Colombia (Kosek et al. 2000, Maguiña et al. 2001). Outbreaks have been de- scribed in non-endemic areas in Peru (Kosek et al. 2000, Sanchez et al. 2006). The outbreak study by Kosek et al. (2000) showed a 77.5\% seroprevalence for B. bacilliformis in 554 individuals tested, and most of the seroreactive patients were asymptomatic. Symptoms in the past year, correlated with serostatus, were fever, bone and joint pain, headache, and verruga peruana. Amano et al. (1997) found a $21 \%$ seroreactivity rate for B. bacilliformis in contacts of index cases in Ecuador.

Description of the acute phase (Maguiña et al. 2001) in 68 patients showed severe anaemia in most, with resultant congestive heart failure and pericardial effusion (possibly secondary to systemic inflammation, septic myocardial dysfunction, and anaemia). Fourteen of the 68 patients had associated neurological symptoms, and CSF analysis showed mononuclear pleocytosis in $3 / 4$ of them. Due to the immunosuppression caused by $B$. bacilliformis, $1 / 3$ of the patients had secondary infections (positive blood cultures to Salmonella typhi and non-typhi and reactivation of toxoplasmosis being the most frequent). Lethality was $9 \%$.

Bartonellosis caused by B. bacilliformis therefore has a wide clinical spectrum and may go undiagnosed or misdiagnosed in a large number of cases. No cases or seroprevalence studies have been reported from Brazil so far, although the areas endemic in Peru are within the Amazon forest.

\section{Diagnosis and treatment of Bartonella infections}

Diagnosis of Bartonella infections can be confirmed by detection of antibodies in patient's serum, by histopathological examination of lymph nodes or tissue biopsy of skin, liver, or other affected organs, and by molecular detection of Bartonella DNA from patients' tissue fragments, CSF or blood (Regnery et al. 1992a, Anderson et al. 1994, Raoult et al. 1994, Dalton et al. 1995, Jalava et al. 1995, Maurin et al. 1997, 2002, Sander et al. 1998, La Scola \& Raoult 1999, Avidor et al. 2001).

Sensitivity of IFA in the diagnosis of CSD varies between $84 \%$ and $95 \%$ using 1:64 titer in commercially available kits. Only $3 \%$ of healthy adults had higher titers to B. henselae (Regnery et al. 1992b, Dalton et al. 1995, Sander et al. 1998, La Scola \& Raoult 1999, Maurin et al. 2002). Bartonella serology is limited by crossreactions between the different species, and also between genera such as Coxiella and Chlamydia (La Scola \& Raoult 1996, Maurin et al. 1997, 2002). Despite these limitations, IFA is the gold standard for the diagnosis of infection, present or previous. Sero-epidemiological studies' primary aim is not to make a diagnosis of active infection, but to show the potential exposure of human or animal populations to an infectious agent. Despite potential limitations in surveys, such as false positive and false negative results, several sero-epidemiological studies have shown their value in alerting scientists as to the dispersion of pathogens, as outlined in this review.

Several antimicrobials have been used widely in the treatment of bartonellosis. The majority of clinical data on therapy has been obtained from small case reports or retrospective reviews (Schutze 2000, Baddour et al. 2005), although there are several in-vitro studies on an- 
tibiotic susceptibility (Maurin \& Raoult 1993, Rolain et al. 2000). There is only one double-blind placebocontrolled study using azithromycin in CSD, involving a small number of patients (Bass et al. 1998), in which 5 -day therapy showed a benefit in lymph node regression in 30 days, as compared with placebo. The treatment response of IHI has been poor and most authors have recommended managing mild to moderate bartonellosis without antimicrobial therapy. Erytromycin, clarithromycin, azithromycin, doxycyclin, either coadministered or not with rifampin, are antimicrobials clearly indicated mainly in immunocompromised patients with bacillary angiomatosis and CSD (Bass et al. 1998, Rolain et al. 2004), and the duration of therapy is 4-6 weeks. Steroid treatment may be used in some cases (Lerdluedeeporn et al. 2003).

A retrospective evalution of patients treated for Bartonella endocarditis concluded that effective antibiotic treatment should include a minimum of two weeks of an aminoglycoside (Raoult et al. 2003). The American Heart Association consensus on treating infective endocarditis, is ceftriaxone plus gentamicin, with or without doxycycline, when Bartonella is suspected, and doxycycline plus gentamicin when Bartonella endocarditis is confirmed (Baddour et al. 2005).

The preferred treatment for the acute phase of Carrion's disease has been chloramphenicol since the 1950s, but ciprofloxacin has been increasingly and successfully used (Maguiña et al. 2001). The treatment of choice for the eruptive phase of Carrion's disease is rifampin, although traditionally, the recommended treatment was intramuscular streptomycin. More recently, ciprofloxaxin has been used with some success, and in vitro susceptibility has shown sensitivity of $B$. bacilliformis to most beta-lactam antibiotics, chloramphenicol, macrolides, tetracyclines, cotrimoxazol, aminoglycosides, and fluoroquinoles.

\section{CONCLUSION}

Bartonellae are widespread in nature. They have several host reservoirs, which are often bacteremic and may serve as a source of infection via arthropod vectors (for example, cat fleas, Ctenocephalides felis) or directly through licks, bites, or scratches. Human infection, except for $B$. bacilliformis, which is distinct in its epidemiology, often occurs irrespective of insect vectors. Such is the case in CSD, FUO, endocarditis, and bacillary angiomatosis, where contact with cats, often non-traumatic, is often reported by patients.

Recognition of neurological and ophthalmologic features of Bartonella infections, which are the most frequent and important complications of CSD, will lead to correct diagnosis and treatment. Also, the recognition of Bartonella spp. as one of the most important microorganisms implicated in blood culture negative endocarditis unassociated with previous antibiotic use will lead to earlier diagnosis and appropriate treatment. The knowledge of the important role of cats as a reservoir in human disease is cause for doctors and nurses to advise their patients of the potential danger of exposure for those with immunosuppressive conditions and those with valvulopathy and/or prosthetic heart valves.
The interest in the study of Bartonella has expanded in recent years in the world and can bring more information in several domains. Further investigations are needed to establish the real situation of Bartonella infections in Brazil, where the diversity of animal species, vertebrates and insect vectors, can be associated with different Bartonella spp., some of which may cause human illnesses with a high public health impact.

\section{REFERENCES}

Abbott RC, Chomel BB, Kasten RW, Floyd-Hawkins KA, Kikuchi Y, Koehler JE, Pedersen NC 1997. Experimental and natural infection with Bartonella henselae in domestic cats. Comp Immunol Microbiol Infect Dis 20: 41-51.

Adams WC, Hindman SM 1954. Cat scratch disease associated with an osteolytic lesion. J Ped 44: 665-669.

Adelson ME, Rao RV, Tilton RC, Cabets K, Eskow E, Fein L, Occi JL, Mordechai E 2004. Prevalence of Borrelia burgdorferi, Bartonella spp, Babesia microti and Anaplasma phagocytophila in Ixodes scapularis ticks collected in Northern New Jersey. J Clin Microbiol 2: 2799-2801.

Al-Majali AM, Al-Qudah KM 2004. Seroprevalence of Bartonella henselae and Bartonella quintana infections in children from Central and Northern Jordan. Saudi Med J 25: 1664-1669.

Amano Y, Rumbea J, Knobloch J, Olson J, Kron M 1997. Bartonellosis in Ecuador: serosurvey and current status of cutaenous verrucous disease. Am J Trop Med Hyg 57: 174-179.

Amaro MH 1996. Infiltrado retiniano na doença da arranhadura do gato. Rev Bras Oftalmol 55: 71-74.

Amaro MH 1998. Neurorretinite, retinite superficial e estrela macular na doença da arranhadura do gato. Rev Bras Oftalmol 57: 783-787.

Anderson B, Sims K, Regnery R, Robinson L, Schmidt MJ, Goral S, Hager C, Edwards K 1994. Detection of Rochalimaea henselae DNA in specimens from cat scratch disease patients by PCR. $J$ Clin Microbiol 32: 942-948.

Antoniou M, Economou I, Wang X, Psaroulaki A, Spyridaki I, Papadopoulos B, Christidou A, Tsafantakis E, Tselentis Y 2002. Fourteen-year seroepidemiological study of zoonoses in a Greek village. Am J Trop Med Hyg 66: 80-85.

Apalsch AM, Nour B, Jaffe R 1993. Systemic cat-scratch disease in a pediatric liver transplant recipient and review of the literature. Pediatr Infect Dis 12: 769-773.

Arisoy EM, Correa AG, Wagner ML, Kaplan S 1999. Hepatosplenic cat-scratch disease in children: selected clinical features and treatment. Clin Infect Dis 28: 778-784.

Avidor B, Graidy M, Efrat G, Leibowitz C, Shapira G, Schattner A, Zimhony O, Giladi M 2004. Bartonella koehlerae, a new catassociated agent of culture-negative human endocarditis. J Clin Microbiol 42: 3462-3468.

Avidor B, Varon M, Marmor S, Lifschitz-Mercer B, Kletter Y, Ephros M, Giladi M 2001. DNA amplification for the diagnosis of catscratch disease in small-quantity clinical specimens. Am J Clin Pathol 115: 900-909.

Azevedo ZM, Higa LY, Boechat PR, Boechat MB, Kaplauch F 2000. Cat scratch disease caused by Bartonella quintana in an infant: an unusual presentation. Rev Soc Bras Med Trop 33: 313-317.

Baddour LM, Wilson WR, Bayer A, Fowler Jr VG, Bolger AF, Levison ME, Ferrieri P, Gerber MA, Tani LY, Gewitz MH, Tong DC, Steckelberg JM, Baltimore RS, Sculman ST, Burns JC, Falace DA, Newburger JW, Pallasch TJ, Takahashi M, Taubert KA 2005. Infective endocarditis diagnosis, antimicrobial therapy, and man- 
agement of complications: A statement for healthcare professionals from the Committee on Rheumatic Fever, Endocarditis, and Kawasaki Disease, Council on Cardiovascular Disease in the Young, and the Councils on Clinical Cardiology, Stroke, and Cardiovascular Surgery and Anesthesia, American Heart Association. Circulation 111: 394-434.

Baker J, Ruiz-Rodriguez R, Whitfeld M, Heon V, Berger TG 1995. Bacillary angiomatosis: a treatable cause of acute psychiatric symptoms in human immunodeficiency virus infection. $J$ Clin Psychiatry 56: 161-166.

Baneth G, Kordick DL, Hegarty BC, Breitschwerdt EB 1996. Comparative seroreactivity to Bartonella henselae and Bartonella quintana among cats from Israel and North Carolina. Vet Microbiol 50: 95-103.

Bass JW, Freitas BC, Freitas AD, Sisler CL, Chan DS, Vencent JM, Person DA, Claybaugh JR, Wittler RR, Weisse ME, Regnery RL, Slater LN 1998. Prospective randomized double blind placebocontrolled evaluation of azithromycin for treatment of cat-scratch disease. Pediatr Infect Dis J 17: 447-452.

Battierman HJ, Peek JA, Loutit JS, Falkow S, Tompkins LS 1995. Bartonella henselae and Bartonella quintana adherence to and entry into cultured human epithelial cells. Infect Immun 63: 4553-4556.

Baylor P, Garoufi A, Karpathios T, Lutz J, Mogelof J, Moseley D 2007. Transverse myelitis in 2 patients with Bartonella henselae infection (cat scratch disease). Clin Infect Dis 45: e42-45.

Benslimani A, Fenollar F, Lepidi H, Raoult D 2005. Bacterial zoonoses and infective endocarditis, Algeria. Emerg Infect Dis 11: 216-224.

Benson LA, Kar S, McLaughlin G, Ihler GM 1986. Entry of Bartonella bacilliformis into erythrocytes. Infect Immun 54: 347-353.

Bergmans AMC, Jong CMA, Amerogngen G, Schot CS, Schouls LM 1997. Prevalence of Bartonella species in domestic cats in the Netherlands. J Clin Microbiol 35: 2256-2261.

Bermond D, Boulouis HJ, Heller R, Van Laere G, Monteil H, Chomel BB, Sander A, Dehio C, Piémont Y 2002. Bartonella bovis sp. nov. and Bartonella capreoli sp. nov., isolated from European ruminants. Int J Syst Evol Microbiol 52: 383-390.

Bernini PM, Gorczyca JT, Modlin JF 1994. Cat-scratch disease presenting as paravertebral abscess. J Bone Jt Surg 76: 1858-1863.

Billeter SA, Levy MG, Chomel BB, Breitschwerdt EB 2008. Vector transmission of Bartonella species with emphasis on the potential for tick transmission. Med Vet Entomol 22: 1-15.

Birtles JB, Harrison TG, Saunders NA, Molyneux DH 1995. Proposal to unify the genera Granhamella and Bartonella, with descriptions of Bartonella talpae comb.nov., Bartonella peromysci comb.nov., and three species, Bartonella grahamii sp.nov., Bartonella taylorii sp.nov. and Bartonella doshiae sp.nov. Int J Syst Bacteriol 45: 1-8.

Blanco JR, Oteo JA, Martínez V, Ramalle E, García A, Ibarra V 1998. Seroepidemiology of Bartonella henselae infection in a risk group. Rev Clin Esp 198: 805-809.

Blanco Ramos J, Oteo JA, Martinez V, Ramalle E, Garcia A, Ibarra V, Rosel L 1999. Seroepidemiology of Bartonella henselae infection in HIV-infected patients. Enferm Infecc Microbiol Clin 17: 434-438.

Boulouis HJ, Chang CC, Henn JB, Kasten RW, Chomel BB 2005. Factors associated with the rapid emergence of zoonotic Bartonella infections. Vet Res 36: 383-410.

Bown KJ, Bennet M, Begon M 2004. Flea-borne Bartonella grahamii and Bartonella taylorii in bank voles. Emerg Infect Dis 11: 684-687.

Breathnach AS, Hoare JM, Eykyn SJ 1997. Culture-negative endocarditis: contribution of bartonella infections. Heart 77: 474-476.
Breitschwerdt EB, Atkins CE, Brown TT, Kordick DL, Snyder PS 1999. Bartonella vinsonii subsp. berkhoffii and related members of the alpha subdivision of the Proteobacteria in dogs with cardiac arrhythmias, endocarditis, or myocarditis. J Clin Microbiol 37: 3618-3626.

Breitschwerdt EB, Kordick DL, Malarkey DE, Keene B, Hadfield TL, Wilson K 1995. Endocarditis in a dog due to infection with a novel Bartonella subspecies. J Clin Microbiol 33: 154-160.

Breitschwerdt EB, Maggi RG, Duncan AW, Nicholson WL, Hegarty BC, Woods CW 2007a. Bartonella species in blood of immunocompetent persons with animal and arthropod contact. Emerg Infect Dis 13: 938-941.

Breitschwerdt EB, Maggi RG, Sigmon B, Nicholson WL 2007b. Isolation of Bartonella quintana from a woman and a cat following putative bite transmission. J Clin Microbiol 45: 270-272.

Brenner DJ, O'Connor S, Winkler HH, Steigerwalt AG 1993. Proposals to unify the genera Bartonella and Rochalimaea, with descriptions of Bartonella quintana comb. nov., Bartonella vinsonii comb.nov. and to remove the family Bartonellaceae from the order Rickettsiales. Int J Syst Bacteriol 43: 777-786.

Brouqui P, Houpikian P, Dupont HT, Toubiana P, Obadia Y, Lafay V, Raoult D 1996. Survey of the seroprevalence of Bartonella quintana in homeless people. Clin Infect Dis 23: 756-759.

Brouqui P, La Scola B, Roux V, Raoult D 1999. Chronic Bartonella quintana bacteremia in homeless patients. $N$ Engl J Med 340: 184-189.

Brouqui P, Raoult D 1996. Bartonella quintana invades and multiplies with endothelial cells in vitro and in vivo and forms intracellular blebs. Res Microbiol 147: 719-731.

Brouqui P, Stein A, Tissot Dupont H, Gallian P, Badiaga S, Rolain JM, Mege JL, LaScola B, Bebis P, Raoult D 2005. Ectoparasitism and vector-borne diseases in 930 homeless people from Marseilles. Medicine 84: 61-68.

Bruneel F, D’Estanque J, Fournier PE, Arlet G, Thuong M, Wolff M, Bédos JP, Lariven S, Regnier B 1998. Isolated right-sided Bartonella quintana endocarditis in an immunocompetent adult. Scand $J$ Infect Dis 30: 424-425.

Carithers HA 1985. Cat-scratch disease. An overview based on a study of 1,200 patients. Am J Dis Child 139: 1124-1133.

Carithers HA, Margileth AM 1991. Cat-scratch disease: acute encephalopathy and other neurologic manifestations. Am J Dis Child 145: 98-101.

Castle KT, Kosoy M, Lerdthusnee K, Phelan L, Bai Y, Gage KL, Leepitakrat W, Monkanna T, Khlaimanee N, Chandranoi K, Jones JW, Coleman RE 2004. Prevalence and diversity of Bartonella in rodents of northern Thailand: a comparison with Bartonella in rodents from southern China. Am J Trop Med Hyg 70: 429-433.

Chamberlin J, Laughlin LW, Romero S, Solorzano N, Gordon S, Andre RG, Pachas P, Friedman H, Ponce C, Watts D 2002. Epidemiology of endemic Bartonella bacilliformis: a prospective cohort study in a Peruvian mountain valley community. J Infect Dis 186: 983-990.

Chang CC, Chomel BB, Kasten RW, Romano V, Tietze N 2001. Molecular evidence of Bartonella spp. in questing adult Ixodes pacificus ticks in California. J Clin Microbiol 39: 1221-1226.

Chang CC, Chomel BB, Kasten RW, Tappero JW, Sanchez MA, Koehler JE 2002. Molecular epidemiology of Bartonella henselae infection in human immunodeficiency virus-infected and their cat contacts, using pulsed-field gel electrophoresis and genotyping. JID 186: 1733-1739.

Chang CC, Kasten RW, Chomel BB, Simpson DC, Hew CM, Kordick DL, Heller R, Piemont Y, Breitschwerdt EB 2000. Coyotes (Canis 
latrans) as the reservoir for a human pathogenic Bartonella sp.: molecular epidemiology of Bartonella vinsonii subsp. berkhoffii infection in coyotes from central coastal California. J Clin Microbiol 38: 4193-4200.

Chang CC, Lee CC, Maruyama S, Lin JW, Pan MJ 2006. Cat-scratch disease in veterinary-associated populations and in its cat reservoir in Taiwan. Vet Res 37: 565-577.

Chomel BB, Boulouis HJ, Maruyama S, Breitschwerdt EB 2006a. Bartonella spp. in pets and effect on human health. Emerg Infect Dis 12: 389-394.

Chomel BB, Boulouis HJ, Petersen H, Kasten RW, Yamamoto K, Chang CC, Gandoin C, Bouillin C, Hew CM 2002. Prevalence of Bartonella infection in domestic cats in Denmark. Vet Res 33: 205-213.

Chomel BB, Carlos ET, Kasten RW, Yamamoto K, Chang CC, Carlos RS, Abenes MV, Pajares CM 1999. Bartonella henselae and Bartonella clarridgeiae infection in domestic cats from the Phillippines. Amer J Trop Med Hyg 60: 593-597.

Chomel BB, Kasten RW, Henn JB, Molia S 2006b. Bartonella infection in domestic cats and wild felids. Ann N Y Acad Sci 1078: 410-415.

Chomel BB, Wey AC, Kasten RW 2003. Isolation of Bartonella washoensis from a dog with mitral valve endocarditis. J Clin Microbiol 41: 5327-5332.

Chrousous GA, Drack AV, Young M, Kattah J, Sirdofsky M 1990. Neuroretinitis and cat scratch disease. J Clin Neuroopthalmol 10: $92-94$

Comer JA, Diaz T, Vlahov D, Monterroso E, Childs JE 2001. Evidence of rodent-associated Bartonella and Rickettsia infections among intravenous drug users from Central and East Harlem, New York City. Am J Trop Med Hyg 65: 855-860.

Comer JA, Flynn C, Regnery RL, Viahov D, Childs JE 1996. Antibodies to Bartonella $\mathrm{sp}$. in inner-city intravenous drug users in Baltimore, Md. Arch Intern Med 156: 2491-2495.

Costa PS, Brigatte ME, Greco DB 2005. Antibodies to Rickettsia rickettsii, Rickettsia typhi, Coxiella burnetii, Bartonella henselae, Bartonella quintana, and Ehrlichia chaffeensis among healthy population in Minas Gerais, Brazil. Mem Inst Oswaldo Cruz 100: 853-859.

Curi ALL, Campos WR, Barbosa L, Lana-Peixoto MA, Oréfice F 2003. Unusual presentation of cat-scratch disease in an HIV positive patient. Br J Ophthalmol 87: 371.

Curi ALL, Machado DO, Heringer G, Campos WR, Oréfice F 2006. Ocular manifestation of cat-scratch disease in HIV-positive patients. Am J Ophthalmol 141: 400-401.

Dalton MJ, Robinson LE, Cooper J, Regnery RL, Olson JG, Childs JE 1995. Use of Bartonella antigens for serologic diagnosis of cat-scratch disease at a national referral centre. Arch Intern Med 155: 1670-1676.

Daly JS, Worthington MG, Brenner DJ, Moss CW, Hollis DG, Weyant RS, Steigerwalt AG, Weaver RE, Daneshvar MI, O'Connor SP 1993. Rochalimaea elizabethae sp. nov. isolated from a patient with endocarditis. J Clin Microbiol 31: 872-881.

Daniels WB, McMurray FG 1954. Cat scratch disease: report of one hundred sixty cases. JAMA 154: 1247-1254.

Diederen BM, Vermeulen MJ, Verbakel H, van der Zee A, Bergmans A, Peeters MF 2007. Evaluation of an internally controlled realtime polymerase chain reaction assay targeting the groEL gene for the detection of Bartonella spp. DNA in patients with suspected cat-scratch disease. Eur J Clin Microbiol Infect Dis 26: 629-633.

Diniz PP, Maggi RG, Schwartz DS, Cadenas MB, Bradley JM, Hegarty B, Breitschwerdt EB 2007. Canine bartonellosis: serologi- cal and molecular prevalence in Brazil and evidence of co-infection with Bartonella henselae and Bartonella vinsonii subsp. berkhoffii. Vet Res 38: 697-710.

Drancourt M, Mainardi JL, Brouqui P, Vandenesch F, Carta A, Lehnert F, Etienne J, Goldstein F, Acar J, Raoult D 1995. Bartonella (Rochalimaea) quintana endocarditis in three homeless men. N Engl J Med 332: 419-423.

Ehrenborg C, Byström R, Hjelm E, Friman G, Holmberg M 2007. High Bartonella spp. seroprevalence in a Swedish homeless population but no evidence of trench fever. Scand J Infect Dis 6: 1-8.

Ellis BA, Regnery RL, Beati L, Bacellar F, Rood M, Glass GG, Marston E, Ksiazek TG, Jones D, Childs JE 1999. Rats of the genus Rattus are reservoir hosts for pathogenic Bartonella species: an Old World origin for a New World disease? J Infect Dis 180: 220-224.

Eremeeva ME, Gerns HL, Lydy SL, Goo JS, Ryan ET, Mathew SS, Ferraro MJ, Holden JM, Nicholson WL, Dasch GA, Koehler JE 2007. Bacteremia, fever, and splenomegaly caused by a newly recognized Bartonella species. N Engl J Med 356: 2381-2387.

Fabbi M, Vicari N, Tranquillo M, Pozzi C, Prati P, De Meneghi D, Bertoletti I, Lauzi S, Guiso P, Genchi C 2004. Prevalence of Bartonella henselae in stray and domestic cats in different Italian areas: evaluation of the potential risk of transmission of Bartonella to humans. Parassitologia 46: 127-129.

Ferres GM, Abarca VK, Prado DP, Montecinos PL, Navarrete CM, Vial CP 2006. Prevalence of Bartonella henselae antibodies in Chilean children, adolescents and veterinary workers. Rev Med Chil 134: 863-867.

Filoni C, Catão-Dias JL, Bay G, Durigon EL, Jorge RSP, Lutz H, Lehmann-Hoffmann R 2006. First evidence of feline Herpesvirus, Calicivirus, Parvovirus, and Ehrlichia exposure in Brazilian free-ranging felids. J Wildlife Dis 42: 470-477.

Fournier PE, Lelievre H, Eykyn SJ, Mainardi JL, Marrie TJ, Bruneel F, Roure C, Nash J, Clave D, James E, Benoit-Lemercier C, Deforges L, Tissot-Dupont H, Raoult D 2001. Epidemiologic and clinical characteristics of Bartonella quintana and Bartonella henselae endocarditis: a study of 48 patients. Medicine 80: 245-251.

Garcia FU, Wojta J, Broadley KN, Davidson JM, Hoover RL 1990. Bartonella bacilliformis stimulates endothelial cells in vitro and is angiogenic in vivo. Am J Pathol 136: 1125-1135.

Garcia-Garcia JA, Baquerizo R, Vargas J, Mira JA, Merchante N, Macias J, Pineda JA 2005. Prevalence of serum antibodies against Bartonella spp. in a healthy population from the south area of the Seville province. Rev Clin Esp 205: 541-544.

Gass JDM 1977. Diseases of the optic nerve that may simulate macular disease. Trans Am Acad Ophthalmol Otolaryngol 83: 76-79.

Gazineo JL, Trope BM, Maceira JP, May SB, Coelho JM, Lambert JS, Nogueira SA 2001. Bacillary angiomatosis: description of 13 cases reported in five reference centers for AIDS treatment in Rio de Janeiro, Brazil. Rev Inst Med Trop S Paulo 43: 1-6.

Golden SF 1993. Hepatosplenic cat-scratch disease associated with elevated anti-Rochalimaea antibody titeres. Pediatr Infect Dis $J$ 12: 868-870.

Greenbaum B, Nelson P, Marchildon M, Donaldson M 1986. Haemolytic anemia and hepatosplenomegaly associated with cat-scratch disease. J Pediatr 108: 428-430.

Groves MG, Harrington KS 1994. Rochalimaea henselae infections: newly recognized zoonoses transmitted by domestic cats. $J \mathrm{Am}$ Vet Med Assoc 204: 267-271.

Guibal F, de La Salmoniere P, Rybojad M, Hadjrabia S, Dehen L, Arlet G 2001. High seroprevalence to Bartonella quintana in home- 
less patients with cutaneous parasitic infestations in downtown Paris. J Am Acad Dermatol 44: 219-223.

Gurfield AN, Boulois HJ, Chomel BB, Heller R, Kasten RW, Yamamoto K, Piémont Y 1997. Coinfection of Bartonella clarridgeiae and Bartonella henselae and with different Bartonella henselae strains in domestic cats. J Clin Microbiol 35: 2120-2123.

Hadfield TL, Warren R, Kass M, Brun E, Levy C 1993. Endocarditis caused by Rochalimaea henselae. Human Pathol 24: 1140-1141.

Hadley S, Albrecht MA, Tarsy D 1995. Cat-scratch encephalopathy: a cause of status epilepticus and coma in a healthy young adult. Neurology 45: 196.

Hamilton DH, Zangwill KM, Hadler JL, Cartter ML 1995. Cat-scratch disease - Connecticut 1992-3. J Infect Dis 172: 570-573.

Harrison TG, Doshi N 1999. Serological evidence of Bartonella spp. infection in the UK. Epidemiol Infect 123: 233-240.

Heller R, Artois M, Xemar V, De Briel D, Gehin H, Jaulhac B, Monteil H, Piemont Y 1997. Prevalence of Bartonella henselae and Bartonella clarridgeiae in stray cats. J Clin Microbiol 35: 1327-1331.

Henn JB, Gabriel MW, Kasten RW, Brown RN, Theis JH, Foley JE, Chomel BB 2007. Gray foxes (Urocyon cinereoargenteus) as a potential reservoir of a Bartonella clarridgeiae-like bacterium and domestic dogs as part of a sentinel system for surveillance of zoonotic arthropod-borne pathogens in northern California. $J$ Clin Microbiol 45: 2411-2418.

Henn JB, Liu CH, Kasten RW, VanHorn BA, Beckett LA, Kass PH, Chomel BB 2005. Seroprevalence of antibodies against Bartonella species and evaluation of risk factors and clinical signs associated with seropositivity in dogs. Am J Vet Res 66: 688-694.

Henn JB, Vanhorn BA, Kasten RW, Kachani M, Chomel BB 2006. Antibodies to Bartonella vinsonii subsp. berkhoffii in Moroccan dogs. Am J Trop Med Hyg 74: 222-223.

Hjelm E, McGill S, Blomqvist G 2002. Prevalence of antibodies to Bartonella henselae, B. elizabethae and B. quintana in Swedish domestic cats. Scand J Infect Dis 34: 192-196.

Hmaimess G, Kadhim H, Saint Martin C, Abu Serieh B, Mousny M, Sebire G 2004. Cat scratch disease presenting as meningomyeloradiculopathy. Arch Dis Child 89: 691-692.

Hoen B, Selton-Suty C, Lacassin F, Etienne J, Briaçon S, Leport C, Canton P 1995. Infective endocarditis in patients with negative blood cultures: analysis of 88 cases from a one-year nation-wide study in France. Clin Infect Dis 20: 501-506.

Holmberg M, Mills JN, McGill S, Benjamin G, Ellis BA 2003. Bartonella infection in sylvatic small mammals of central Sweden. Epidemiol Infect 130: 149-157.

Holmes AH, Greenough TC, Balady GJ, Regnery RL, Anderson BE, O'Keane JC, Fonger JD, McCrone EL 1995. Bartonella henselae endocarditis in an immunocompetent adult. Clin Infect Dis 21: 1004-1007.

Honadel TE, Chomel BB, Yamamoto K, Chang C, Farver TB 2001. Seroepidemiology of Bartonella vinsonii subsp. berkhoffii exposure among healthy dogs. J Am Vet Med Assoc 219: 480-484.

Hong PH, Jampol LM, Dodwell DG, Hrisomalos NF, Lyon AT 1997. Unifocal helioid choroiditis.Arch Ophthalmol 115: 1007-1013.

Houpikian P, Raoult D 2005. Blood culture negative endocarditis in a reference center: etiologic diagnosis of 348 cases. Medicine 84: $162-173$

Huarcaya E, Maguiña C, Merellog J, Cok J, Birtles R, Infante B, Vidal J, Tello A, Ventosilla P 2002. A prospective study of cat-scratch disease in Lima-Peru. Rev Inst Med Trop S Paulo 44: 325-330.
Hulzebos CV, Koetse HA, Kimpen JL, Wolfs TF 1999. Vertebral osteomyelitis associated with cat-scratch disease. Clin Infect Dis 28: $1310-1312$.

Jackson LA, Spach DH, Kippen DA 1996. Seroprevalence of Bartonella quintana among patients at a community clinic in downtown Seattle. J Infect Dis 173: 1023-1026.

Jacobs RF, Schutze GE 1998. Bartonella henselae as a cause of prolonged fever and fever of unknown origin in children. Clin Infect Dis 26: 80-84.

Jacomo V, Kelly PJ, Raoult D 2002. Natural history of Bartonella infections (an exception to Koch's postulate). Clin Diagn Lab Immunol 9: 8-18.

Jalava J, Kotilainen P, Nikkari S, Skurnik M, Väntinnen E, Lehtonen OP, Eerola E, Toivaren P 1995. Use of the polymerase chain reaction and DNA sequencing for detection of Bartonella quintana in the aortic valve of a patient with culture-negative infective endocarditis. Clin Infect Dis 21: 891-896.

Jardine C, Appleyard G, Kosoy MY, McColl D, Chirino-Trejo M, Wobeser G, Leighton FA 2005. Rodent-associated Bartonella in Saskatchewan, Canada. Vector Borne Zoonotic Dis 5: 402-409.

Johnson JF, Lehaman RM, Shiels WE, Blaney SM 1985. Osteolysis is cat-scratch fever. Radiology 156: 373-374.

Katner HP, Treen B, Pankey GA, Glasgow S, Crotez LM, Dalovisio J 1986. Pleural effusion and anicteric hepatitis associated with cat scratch disease. Documentation by cat scratch bacillus. Chest 89: 302-303.

Kelly K, Rolain JM, Maggi R, Sontakke S, Keene B, Hunter S, Lepidi H, Breitschwerdt KT, Breitschwerdt EB 2006. Bartonella quintana endocarditis in dogs. Emerg Infect Dis 12: 1869-1872.

Kerkhoff FT, Bergmans AM, van Der Zee A, Rothova A 1999. Demonstration of Bartonella grahamii DNA in ocular fluids of a patient with neuroretinitis. J Clin Microbiol 37: 4034-4038.

Kikuchi E, Maruyama S, Sakai T, Tanaka S, Yamaguchi F, Hagiwara T, Katsube Y, Mikami T 2002. Serological investigation of Bartonella henselae infections in clinically cat-scratch disease-suspected patients, patients with cardiovascular diseases, and healthy veterinary students in Japan. Microbiol Immunol 46: 313-316.

Kodama T, Masuda H, Ohira A 2003. Neuroretinitis associated with cat-scratch disease in Japanese patients. Acta Ophthalmol Scand 81: 653-657.

Koehler JE, Glaser CA, Tappero JW 1994. Rochalimaea henselae infection: a new zoonosis with the domestic cat as a reservoir. JAMA 271: 531-535.

Koehler JE, Sanchez MA, Tye S, Garrido-Rowland CS, Chen FM, Maurer T, Cooper JL, Olson JG, Reingold AL, Hadley WK, Regnery RR, Tappero JW 2003. Prevalence of Bartonella infection among human immunodeficiency virus-infected patients with fever. Clin Infect Dis 37: 559-566.

Kordick DL, Breitschwerdt EB 1995. Intraerythrocytic presence of Bartonella henselae. J Clin Microbiol 33: 1655-1656.

Kordick DL, Brown TT, Shin K, Breitschwerdt EB 1999. Clinical and pathological evaluation of chronic Bartonella henselae or Bartonella clarridgeiae infection in cats. J Clin Microbiol 35: 1536-1547.

Kordick DL, Hilyard EJ, Hadfiel TL, Wilson KH, Steigerwalt AG, Brenner DJ, Breitschwerdt EB 1997. Bartonella clarridgeae, a newly recognised zoonotic pathogen causing inoculation papules, fever and lymphadenopathy (cat -scratch disease). J Clin Microbiol 35: 1813-1818.

Kosek M, Lavarello R, Gilman RH, Delgado J, Maguiña C, Verástegui M, Lescano AG, Mallqui V, Kosek JC, Recavarren S, Cabrera 
L 2000. Natural history of infection with Bartonella bacilliformis in a nonendemic population. JID 182: 865-872.

Kosoy M, Morway C, Sheff KW, Bai Y, Colborn J, Chalcraft L, Dowell SF, Peruski LF, Maloney SA, Baggett H, Sutthirattana S, Sidhirat A, Maruyama S, Kabeya H, Chomel BB, Kasten R, Popov V, Robinson J, Kruglov A, Petersen LR 2008. Bartonella tamiae sp. nov., a newly recognized pathogen isolated from three human patients from Thailand. J Clin Microbiol 46: 772-775.

Kosoy M, Murray M, Gilmore RD Jr, Bai Y, Gage KL 2003. Bartonella strains from ground squirrels are identical to Bartonella washoensis isolated from a human patient. J Clin Microbiol 41: 645-650.

Krause R, Wenisch C, Fladerer P, Daxbock F, Krejs GJ, Reisnger EC 2000. Osteomyelitis of the hip joint associated with systemic catscratch disease in an adult. Eur J Clin Microbiol Infect Dis 19: 781-783.

Kumasaka K, Arashima Y, Yanai M, Hosokawa N, Kawano K 2001. Survey of veterinary professionals for antibodies to Bartonella henselae in Japan. Rinsho Byori 49: 906-910.

La VD, Tran-Hung L, Aboudharam G, Raoult D, Drancourt M 2005. Bartonella quintana in domestic cats. Emerg Infect Dis 11: 1287-1289.

Lamas C, Eykyn J 2003. Blood culture negative endocarditis: analysis of 63 cases presenting over 25 years. Heart 89: 258-262.

Lamas C, Favacho A, Ramos RG, Santos MS, Ferraiuoli GI, Weksler C, Rozental T, Bóia MN, Lemos ERS 2007. Bartonella endocarditis: the first Brazilian case alive and well. Braz J Infect Dis 11: 591-594.

Lamas C, Rozental T, Favacho A, Bóia MN, Maduro R, Oliveira AP, Lemos ERS 2006. Bartonella sp. infections in HIV positive individuals in Rio de Janeiro, Brazil. Int J Infect Dis 10 (Suppl. 1): S176.

La Scola B, Raoult D 1996. Serological cross-reactions between Bartonella quintana, Bartonella henselae and Coxiella burnetii. $J$ Clin Microbiol 34: 2270-2274.

La Scola B, Raoult D 1999. Culture of Bartonella quintana and Bartonella henselae from human samples, a 5-year experience (1993-1998). J Clin Microbiol 37: 1899-1905.

Lawson PA, Collins MD 1996. Description of Bartonella clarridgeiae sp. nov. isolated from the cat of a patient with Bartonella henselae septicemia. Med Microbiol Lett 5: 64-73.

Lerdluedeeporn P, Krogstad P, Roberts RL, Stiehm ER 2003. Oral corticosteroids in cat-scratch disease. Clin Pediatr 42: 71-73.

Lewis DW, Tucker SH 1986. Central nervous system involvement in cat-scratch disease. Pediatrics 77: 714-721.

Li DM, Liu QY, Yu DZ, Zhang JZ, Gong ZD, Song XP 2007. Phylogenetic analysis of bartonella detected in rodent fleas in Yunnan, China. J Wildl Dis 43: 609-617.

Lucey D, Dolan MJ, Moss CW, Garcia M, Hollis DG, Wegner S, Morgan G, Almeida R, Leong D, Greisen KS 1992. Relapsing illness due to Rochalimaea henselae in immunocompetent hosts: implication for therapy and new epidemiological associations. Clin Infect Dis 14: 683-688.

Lyon LW 1971. Neurologic manifestations of cat-scratch disease. Arch Neurol 25: 23-27.

Magalhães RF, Pitassi LHU, Salvadego M, Moraes AP, Barjas-Castro ML, Velho PEF 2007. Bartonella henselae survives after the storage period of the red blood cell units. ASH Annual Meeting Abstracts 110: 2906

Maggiore G, Massei F, Bussani R, Ventura A 1999. Bone pain after lymphadenitis. Eur J Pediatr 158: 165-166.
Maguiña C, Garcia PJ, Gotuzzo E, Cordero L, Spach D 2001. Bartonellosis (Carrion's disease) in the modern era. Clin Infect Dis 33: 772-779.

Maillard R, Grimard B, Chastant-Maillard S, Chomel B, Delcroix T, Gandoin C, Bouillin C, Halos L, Vayssier-Taussat M, Boulouis HJ 2006. Effects of cow age and pregnancy on Bartonella infection in a herd of dairy cattle. J Clin Microbiol 44: 42-46.

Mainardi J, Drancourt M, Roland J, Gestin JL, Raoult D, Acar JF, Goldstein FW 1996. A new case of Bartonella (Rochalimaea) quintana endocarditis in an Algerian farmer. Clin Microbiol Infect 1: 275-276.

Margileth AM 1992. Antibiotic therapy for cat-scratch disease: a clinical study of therapeutic outcome in 268 patients and a review of the literature. Pediatr Infect Dis J 11: 474-478.

Margileth AM, Wear DJ, English CK 1987. Systemic cat-scratch disease: report of 23 patients with prolonged or recurrent severe bacterial infection. J Infect Dis 155: 390-404.

Maruyama S, Boonmar S, Morita Y, Sakai T, Tanaka S, Yamaguchi F, Kabeya H, Katsube Y 2000. Seroprevalence of Bartonella henselae and Toxoplasma gondii among healthy individuals in Thailand. J Vet Med Sci 62: 635-637.

Massei F, Messina F, Gori L, Macchia P, Maggiore 2004. High prevalence of antibodies to Bartonella henselae among Italian children without evidence of cat scratch disease. Clin Infect Dis 38: 145-148

Maurin M, Etienne J, Raoult D 1997. Serological cross-reactions between Bartonella and Chlamydia species: implications for diagnosis. J Clin Microbiol 35: 2283-2287.

Maurin M, Raoult D 1993. Antimicrobial susceptibility of Rochalimaea quintana, Rochalimaea vinsonii, and the newly recognized Rochaliamaea henselae. J Antimicrob Chemother 32: 587-594.

Maurin M, Rolain JM, Raoult D 2002. Comparison of in-house and commercial slides for detection of immunoglobulin $\mathrm{G}$ and $\mathrm{M}$ by immunofluorescence against Bartonella henselae and Bartonella quintana. Clin Diagn Lab Immunol 9: 1004-1009.

McGill S, Wesslen L, Hjelm E, Holmberg M, Auvinen MK, Berggren K, Grandin-Jarl B, Johnson U, Wikstrom S, Friman G 2005. Bartonella spp. seroprevalence in healthy Swedish blood donors. Scand J Infect Dis 37: 723-730.

Mediannikov O, Ivanov L, Zdanovskaya N, Vysochina N, Fournier PE, Tarasevich I, Raoult D 2005. Molecular screening of Bartonella species in rodents from the Russian Far East. Ann N Y Acad Sci 1063: 308-311.

Miller P, Bell WE 1980. Cat-scratch disease with encephalopathy. Clin Ped 19: 233-234.

Mohle-Boetani JC, Koehler JE, Berger TG, LeBoit P, Kemper CA, Reingold A, Plikaytis BD, Wenger JD, Tappero JW 1996. Bacillary angiomatosis and bacillary peliosis in patients infected with human immunodeficiency virus: clinical characteristics in a case-control study. Clin Infect Dis 22: 794-800.

Murakami K, Tsukahara M, Tsuneoka H, Iino H, Ishida C, Tsujino K, Umeda A, Furuya T, Kawauchi S, Sasaki K 2002. Cat scratch disease: analysis of 130 seropositive cases. J Infect Chemother 8: 349-352.

Noah DL, Bresee JS, Gorensek MJ, Rooney JA, Cresanta JL, Regnery RL, Wong J, Del Toro J, Olson JG, Childs JE 1995. Cluster of five children with acute encephalopathy associated with cat-scratch disease in South Florida. Pediatr Infect Dis J 14: 866-869.

Noah DL, Kramer CM, Verbsky MP, Rooney JA, Smith KA, Childs JE 1997. Survey of veterinary professionals and other veterinary conference attendees for antibodies to Bartonella henselae and B.quintana. J Am Vet Med Assoc 210: 342-344. 
Oliveira AHP, Pereira CAP, Sousa LB, Freitas D 2004. Conjuntivite granulomatosa atípica causada pela doença da arranhadura do gato: relato de caso. Arq Bras Oftalmol 67: 541-543.

O'Reilly KL, Bauer RW, Freeland RL, Foil LD, Hughes KJ, Rohde KR, Roy AF, Stout RW, Triche P 1999. Acute clinical disease in cats following infection with a pathogenic strain of Bartonella henselae (LSU 16). Infect Immun 67: 3066-3072.

Ormerod LD, Skolnick KA, Menosky MM, Pavan PR, Pon DM 1998. Retinal and choroidal manifestations of cat-scratch disease. $O p h$ thalmology 105: 1024-1031.

O’Rourke LG, Pitulle C, Hegarty B, Kraycirik S, Killary KA, Grosenstein P, Brown JW, Breitschwerdt EB 2005. Bartonella quintana in Cynomolgus monkey (Macaca fascicularis). Emerg Infect Dis 11: 1931-1934.

Pinto Jr VL, Curi AL, Pinto AS, Nunes EP, Teixeira MLB, Rozental T, Favacho AR, Bóia MN, Lemos ERS 2008. Cat scratch disease complicated with aseptic meningitis and neuroretinitis. Braz $J$ Infect Dis 12: 158-160.

Podsiadly E, Chmielewski T, Marczak R, Sochon E, Tylewska-Wierzbanowska S 2007. Bartonella henselae in the human environment in Poland. Scand J Infect Dis 1: 1-7.

Pollock SC, Kristinsson J 1998 Cat-scratch disease manifesting as helioid unifocal choroiditis. Arch Ophthalmol 116: 1249-1250.

Ramos AJ, Vargas J, Fernández-Rivera J, Macías J, Mira JA, Pinea JA 2002. Prevalencia de seropositividad para Bartonella spp. en pacientes adictos a drogas por vía parenteral infectados y no infectados por el virus de la inmunodeficiencia humana. Med Clin (Barc) 119: 565-567.

Raoult D, Fournier PE, Drancourt M, Marrie TJ, Etienne J, Cosserat J, Cacoub P, Poinsignon Y, Leclercq P, Sefton AM 1996. Diagnosis of 22 new cases of Bartonella endocarditis. Ann Intern Med 125: 646-652.

Raoult D, Fournier PE, Vandenesch F, Mainardi JL, Eykyn SJ, Nash J, James E, Benoir-Lemercier C, Marrie TJ 2003. Outcome and treatment of Bartonella endocarditis. Arch Intern Med 163: 226-230.

Raoult D, La Scola B, Kelly PJ, Davoust B, Gomez J 2005. Bartonella bovis in cattle in Africa. Vet Microbiol 105: 155-156.

Raoult D, Tissot-Dupont H, Enea-Mutillod M 1994. Positive predictive value of Rochaliamaea henselae antibodies in the diagnosis of cat-scratch disease. Clin Infect Dis 19: 355.

Rath PM, von Recklinghausen G, Ansorg R 1997. Seroprevalence of immunoglobulin $\mathrm{G}$ antibodies to Bartonella henselae in cat owners. Eur J Clin Microbiol Infect Dis 16: 326-327.

Reed JB, Scales DK, Wong MT, Lattuada CP Jr, Dolan MJ, Schwab IR 1998. Bartonella henselae neuroretinitis in cat scratch disease. Diagnosis, management, and sequelae. Ophthalmology 105: 459-466.

Regnery RL, Anderson BE, Clarridge JE III, Rodrigues-Barradas MC, Jones DC, Carr JH 1992a. Characterization of a novel Rochalimaea species, $R$. henselae sp. nov., isolated from blood of a febrile human immunodeficiency virus-positive patient. J Clin Microbiol 30: 265-274.

Regnery RL, Childs JE, Koehler JE 1995. Infections associated with Bartonella in persons infected with human immunodeficiency virus. Clin Infect Dis 21 (Suppl. 1): S94-98.

Regnery RL, Martin M, Olson J 1990. Naturally occurring Rochalimaea henselae infection in the domestic cat. Lancet 340: 557-558.

Regnery RL, Olson JG, Perkins BA, Bibb W 1992b. Serological response to Rochalimeae henselae antigen in suspected cat-scratch disease. Lancet 339: 1443-1445.

Regnery RL, Rooney DVM, Johnson MS, Nesby SL, Manzewitsch P, Beaver K, Olson JG 1996. Experimentally induced Bartonella henselae infections followed by challenge exposure and antimicrobial therapy in cats. Amer J Vet Med 57: 1714-1719.

Resto-Ruiz S, Burgess A, Anderson BE 2003. The role of host immune response in pathogenesis of Bartonella henselae. DNA Cell Biol 22: 431-440.

Ricketts WE 1949. Clinical manifestations of Carrión's disease. Arch Intern Med 84: 751-781.

Ridder GJ, Boedeker CC, Techanu-Ihling K, Grunow R, Sander A 2002. Role of cat-scratch disease in lymphadenopathy of the head and neck. Clin Infect Dis 35: 643-649.

Riviello JJ Jr, Ruoff KL 1998. Case records of Massachussets General Hospital: an 11-year-old with seizure. $N$ Engl J Med 338: 112-119.

Robson JMB, Harte GJ, Osborne DRS, McCormack JG 1999. Catscratch disease with paravertebral mass and osteomyelitis. Clin Infect Dis 28: 274-278

Rocha JL, Pellegrino LN, Riella LV, Martins LT 2004. Acute hemiplegia associated with cat-scratch disease. Braz J Infect Dis 8: 263-266.

Rolain JM, Brouqui P, Koehler JE, Maguina C, Dolan MJ, Raoult D 2004. Recommendations for treatment of human infections caused by Bartonella species. Antimicrob Agents Chemother 48: 1921-1933.

Rolain JM, Franc M, Davous B, Raoult D 2003. Molecular detection of Bartonella quintana, B. koehlerae, B. henselae, B.clarridgeiae, Rickettsia felis and Wolbachia pipiensis in cat fleas, France. Emerg Infect Dis 9: 338-342.

Rolain JM, Maurin M, Raoult D 2000. Bactericidal effect of antibiotics on Bartonella and Brucella spp.: clinical implications. $J$ Antimicrob Chemother 46: 811-814.

Rotily M, Obadia Y, Tissot-Dupont H, Cavailler P, Raoult D 1996. The epidemiology of trench fever: a pilot study in homeless people in Marseilles. Sante 6: 275-278.

Roux V, Eykyn SJ, Wyllie S, Raoult D 2000. Bartonella vinsonii subsp. berkhoffii as an agent of afebrile blood culture negative endocarditis in a human. J Clin Microbiol 38: 1698-1700.

Sanchez E, Perez E, Venocilla P, Merello J, Revilla L, Guevara Z, Birtles R, Raoult D 2006. Epidemiology of Bartonella bacilliformis in new endemic areas in the jungle of Amazonas. Int $J$ Infect Dis 10 (Suppl. 1): 13.

Sander A, Posselt M, Oberle K, Bredt W 1998. Seroprevalence of antibodies to Bartonella henselae in patients with cat-scratch disease and in healthy controls: evaluation and comparison of two commercial serological tests. Clin Diagn Lab Immunol 5: 486-490.

Schattner A, Zimhony O, Avidor B, Giladi M 2003. Asking the right question. Lancet 361: 1786.

Schutze GE 2000. Diagnosis and treatment of Bartonella henselae infections. Pediatr Infect Dis J 19: 1185-1188.

Schwartzman WA, Patnaik M, Angulo FJ, Visscher BR, Miller EM, Peter JB 1995. Bartonella (Rochalimaea) antibodies, dementia and cat ownership among men infected with human immunodeficiency virus. Clin Infect Dis 21 :954-959.

Seki N, Sasaki T, Sawabe K, Sasaki T, Matsuoka M, Arakawa Y, Marui E, Kobayashi M 2006. Epidemiological studies on Bartonella quintana infections among homeless people in Tokyo, Japan. Jpn J Infect Dis 59: 31-35.

Selby G, Walker GL 1979. Cerebral arteritis in cat scratch disease. Neurol 29: 1413-1418.

Siciliano RF, Strabelli TM, Zeigler R, Rodrigues C, Castelli JB, Grinberg M, Colombo S, da Silva LJ, do Nascimento EMM, dos Santos FCP, Uip DE 2006. Infective endocarditis due to Bartonella spp and Coxiella burnetii. Experience at a Cardiology Hospital in São Paulo, Brazil. Ann N Y Acad Sci 1078: 215-222. 
Skerget M, Wenisch C, Daxboeck F, Krause R, Haberl R, Stuenzner D 2003. Cat or dog ownership and seroprevalence of ehrlichiosis, Q fever, and cat-scratch disease. Emerg Infect Dis 9: 1337-1340.

Slhessarenko N, Camargo MCGO, D’Auria SRN 1996. Soroprevalência de Bartonella henselae em gatos do município de São Paulo. Rev Soc Bras Med Trop 29: 104.

Smith HM, Reporter R, Rood MP, Linscott AJ, Mascola LM, Hogrefe W, Purcell RH 2002. Prevalence study of antibody to rat-borne pathogens and other agents among patients using a free clinic in Downtown Los Angeles. J Infect Dis 186: 1673-1676.

Soheilian M, Markomichalakis N, Foster CS 1996. Intermediate uveitis and retinal vasculitis as manifestation of cat-scratch disease. Am J Ophthalmol 122: 582-584.

Solano-Gallego L, Bradley J, Hegarty B, Sigmon B, Breitschwerdt E 2004. Bartonella henselae $\mathrm{IgG}$ antibodies are prevalent in dogs from southeastern USA. Vet Res 35: 585-595.

Solley WA, Martin DF, Newman NJ, King R, Callanan DG, Zacchei T, Wallace RT, Parks DJ, Bridges W, Sternberg P Jr 1999. Cat scratch disease: posterior segment manifestations. Ophthalmology 106: 1546-1553.

Spach DH, Callis KP, Paauw DS, Houze YB, Schoenknecht FD, Welch DF, Rosen H, Brenner DJ 1993. Endocarditis caused by Rochalimaea quintana in a patient infected with human immunodeficiency virus. J Clin Microbiol 31: 692-694.

Spach DH, Kanter AS, Daniels NA, Nowowiejski DJ, Larson AM, Schmidt RA, Swaminathan B, Brenner DJ 1995a. Bartonella (Rochalimaeae) species as a cause of apparent 'culture-negative' endocarditis. Clin Infect Dis 20: 1044-1047.

Spach DH, Kanter AS, Dougherty MJ, Larson AM, Coyle MB, Brenner DJ, Swaminathan B, Matar GM, Welch DF, Root RK, Stamm WE 1995b. Bartonella (Rochalimaea) quintana bacteremia in inner city patients with chronic alcoholism. $N$ Engl $J$ Med 332: 424-428

Spaulding WB, Hennessy JN 1960. Cat scratch disease: a study of eighty-three cases. Am J Med 28: 504-509.

Stein A, Raoult D 1995. Return of trench fever. Lancet 345: 450-451.

Stevens H 1952. Cat- scratch fever encephalitis. AJDC 84: 218-222.

Stockmeyer B, Schoerner C, Frangou P, Moriabadi T, Heuss D, Harrer T 2007. Chronic vasculitis and polyneuropathy due to infection with Bartonella henselae. Infection 35: 107-109.

Suhler EB, Lauer AK, Rosenbaum JT 2000. Prevalence of serologic evidence of cat scratch disease in patients with neuroretinitis. Ophthalmology 107: 871-876.

Sweeney VP, Drance SM 1970. Optic neuritis and compressive neuropathy associated with cat-scratch disease. Can Med Assoc J 103: 1380-1381.

Tappero JW, Mohle-Boetani JC, Koehler JE, Swaminathan B, Berger TG, LeBoit PE, Smith LL, Wenger JD, Pinner RW, Kemper CA 1993. The epidemiology of bacillary angiomatosis and bacillary peliosis. JAMA 269: 770-775.

Tea A, Aleixiou-Daniel S, Arvanitidou M, Diza E, Antoniadis A 2003. Occurrence of Bartonella henselae and Bartonella quintana in a healthy Greek population. Am J Trop Med Hyg 68: 554-556.

Tolan RW Jr, Schibler KR, Galliani CA, Kleiman NB 1990. Unusual, systemic, pseudo-malignant manifestation of cat scratch disease in siblings. Pediatr Infect Dis J 9: 913-916.

Tsukahara M, Tsuneoka H, Ino H, Ohno K, Murano I 1998. Bartonella henselae infection from a dog. Lancet 352: 1682.
Velho PE, Velho PV, Del Negro GM, Okay TS, Diniz PP, Breitschwerdt EB 2007.Severe anemia, panserositis, and cryptogenic hepatitis in an HIV patient infected with Bartonella henselae. Ultrastruct Pathol 31: 373-377.

Velho PENF, Souza EM, Cintra ML, Moraes AM, Tanaka AMU 2006. Diagnóstico da infecção por Bartonella spp: a propósito de um caso de angiomatose bacilar. An Bras Dermatol 81: 349-353.

Ventura A, Massei F, Not T, Massimetti M, Bussani R, Maggiore G 1999. Systemic Bartonella infection with hepatosplenic involvement. J Pediatr Gastroenterol Nutr 29: 52-56.

Wade NK, Levil L, Jones MR, Bhisitkul R, Fine L, Cunninghan ET Jr 2000. Optic disk edema associated with peripapillary serous retinal detachment; an early sign of systemic Bartonella henselae infection. Am J Ophthalmol 130: 327-334.

Waldwogel K, Regnery RL, Anderson BE, Cuduff R, Cuduff J, Nadal D 1994. Disseminated cat-scratch disease: detection of Rochalimaea henselae in affected tissue. Eur J Pediatr 153: 23-27.

Walter RS, Eppes SC 1998. Cat scratch disease presenting with peripheral facial nerve paralysis. Pediatrics 101: E13.

Wear DJ, Malaty RH, Zimmerman LE, Hadfield TL, Margileth AM 1985. Cat scratch disease bacilli in the conjunctiva of patients with Parinaud's oculoglandular syndrome. Ophthalmology 92: 1282-1287.

Wear DJ, Margileth AM, Hadfield TL, Fisher GW, Schlagel CJ, King FM 1983. Cat-scratch disease: a bacterial infection. Science 221: 1403-1405.

Whitman BW, Krafte-Jacobs B 1995. Cat-scratch disease associated with pleural effusions and encephalopathy in a child. Respiration 62: 171-173.

Wikswo ME, Hu R, Metzger ME, Eremeeva ME 2007. Detection of Rickettsia rickettsii and Bartonella henselae in Rhipicephalus sanguineus ticks from California. J Med Entomol 44: 158-162.

Wong MT, Dolan MJ, Lattuada CP Jr, Regnery RL, Garcia ML, Mokulis EC, La Barre RA, Ascher DP, Delmar JÁ, Kelly JW 1995. Neuroretinitis, aseptic meningitis, and lymphadenitis associated with Bartonella (Rochalimaea) henselae infection in immunocompetent patients and patients infected with human immunodeficiency virus type 1. Clin Infect Dis 21: 352-360.

Yamashita CA, Mielle A, Slhessarenko N, Nascimento S, Gilio A, Pahl M, Ejzenberg B, Baldacci E, Okay Y 1996. Parinaud syndrome caused by Bartonella henselae: case report. Rev Inst Med Trop S Paulo 38: 437-440.

Zangwill KM, Hamilton DH, Perkins BA, Regnery RL, Plikaytis BD, Adler JL, Cartter ML, Wenger JD 1993. Cat scratch disease in Connecticut: epidemiology, risk factors and evaluation of a new diagnostic test. $N$ Engl J Med 329: 8-13.

Zanutto MS, Mamizuka EM, Raiz-Júnior R, Lima TM, Diogo CL, Okay TS, Hagiwara MK 2001. Experimental infection and horizontal transmission of Bartonella henselae in domestic cats. Rev Inst Med Trop S Paulo 43: 257-261.

Zarkovic A, McMurray C, Deva N, Ghosh S, Whitley D, Guest S 2007. Seropositivity rates for Bartonella henselae, Toxocara canis and Toxoplasma gondii in New Zealand blood donors. Clin Experiment Ophthalmol 35: 131-134.

Zeaiter Z, Fournier PE, Ogata H, Raoult D 2002. Phylogenetic classification of Bartonella species by comparing groEL sequences. Int J Syst Evol Microbiol 52: 165-171.

Znazen A, Rolain JM, Hammami N, Kammoun S, Hammami A, Raoult D 2005. High prevalence of Bartonella quintana endocarditis in Sfax, Tunisia. Am J Trop Med Hyg 72: 503-507. 